\title{
Acute pulmonary embolism multimodality imaging prior to endovascular therapy
}

\author{
David $\operatorname{Sin}^{1}$. Gordon McLennan ${ }^{1} \cdot$ Fabian Rengier ${ }^{2} \cdot$ Ihab Haddadin $^{1} \cdot$ Gustavo A. Heresi ${ }^{3} \cdot$ John R. Bartholomew ${ }^{4}$. \\ Matthias A. Fink ${ }^{2}$. Dustin Thompson ${ }^{1}$. Sasan Partovi ${ }^{1}$ (I)
}

Received: 28 July 2020 / Accepted: 19 August 2020 / Published online: 30 August 2020

(c) Springer Nature B.V. 2020

\begin{abstract}
The manuscript discusses the application of CT pulmonary angiography, ventilation-perfusion scan, and magnetic resonance angiography to detect acute pulmonary embolism and to plan endovascular therapy. CT pulmonary angiography offers high accuracy, speed of acquisition, and widespread availability when applied to acute pulmonary embolism detection. This imaging modality also aids the planning of endovascular therapy by visualizing the number and distribution of emboli, determining ideal intra-procedural catheter position for treatment, and signs of right heart strain. Ventilation-perfusion scan and magnetic resonance angiography with and without contrast enhancement can also aid in the detection and pre-procedural planning of endovascular therapy in patients who are not candidates for CT pulmonary angiography.
\end{abstract}

Keywords Acute pulmonary embolism · Computed tomography pulmonary angiography $\cdot$ Ventilation-perfusion scan . Magnetic resonance angiography

\section{Introduction}

Acute pulmonary embolism (PE) is a frequently encountered disease associated with high morbidity and mortality [1]. Most cases of acute PE originate from lower extremity deep vein thrombosis [2]. The thirty-day mortality rate is estimated to be $4 \%$, and the one-year mortality rate is estimated to be $13 \%$ [3]. The incidence of acute PE is higher in males (56 per 100,000 people) compared to females (48 per 100,000 people) [4-6]. Advanced age is correlated with increased incidence of acute PE [5, 7].

Sasan Partovi

sxp509@case.edu

1 Section of Interventional Radiology, Imaging Institute, Cleveland Clinic Main Campus, Cleveland, OH, USA

2 Section of Emergency Radiology, Clinic for Diagnostic and Interventional Radiology, University Hospital Heidelberg, Heidelberg, Germany

3 Department of Pulmonary and Critical Care Medicine, Respiratory Institute, Cleveland Clinic Main Campus, Cleveland, OH, USA

4 Section of Vascular Medicine, Heart and Vascular Institute, Cleveland Clinic Main Campus, Cleveland, OH, USA

\section{Clinical evaluation of suspected acute PE}

Acute PE presents with variable severity [8-11]. This can be explained by the varying degrees of pulmonary vasculature obstruction secondary to venous thromboembolism. Gradual increases in pulmonary artery pressure can be seen when greater than $30-50 \%$ of an arterial bed's cross-sectional area is occluded as a result of stressed endothelial cells releasing thromboxane and other vasoactive mediators [12]. Increased pulmonary artery pressure resulting from acute PE obstruction increases right heart strain secondary to elevated right ventricular afterload [13]. Right ventricular dysfunction can be observed acutely as a result of the increased afterload as well as myocardial ischemia [2]. Continued stress on the ventricles can cause protracted contractions, ischemia, and desynchronization of the left and right ventricles [14]. Prolonged elevation of pulmonary vascular pressures can also cause pulmonary hypertension that lasts beyond the original event [15]. Dyspnea, pleuritic chest pain, and cough are the most common presenting symptoms of acute PE, while other signs of acute PE include unilateral leg edema, sinus tachycardia, and tachypnea [16, 17].

Initial testing for patients with suspected acute PE should include brain natriuretic peptide, troponin, and ECG (Table 1). These investigations can be helpful in narrowing 
down the differential diagnosis. These tests also provide prognostic data when acute PE is present [9, 10, 18-29].

The Wells score is used to determine the pre-test probability of acute PE in hemodynamically stable patients. A patient's Wells score categorizes them as having a low, intermediate, or high pre-test probability of acute PE $[1,2,32$, 33]. The low, intermediate, and high risk categories correspond to $5.7 \%, 23.2 \%$, and $49.3 \%$ pre-test probability of acute PE, respectively based on a 2010 meta-analysis [34]. A Wells score of zero essentially excludes the possibility of acute PE with a low false-negative rate and a high sensitivity. The modified Geneva score may also be used to determine the pre-test probability of acute PE. This scoring system utilizes clinical variables to categorize a patient into low, intermediate, or high risk groups that corresponded to $8 \%, 28 \%$, and $74 \%$ prevalence of acute PE in one study [35]. A simplified version of the modified Geneva score has been found to maintain diagnostic accuracy and has been externally validated $[36,37]$.

Patients who are categorized as having a low or intermediate pre-test probability of acute PE can be assessed with a laboratory D-dimer test. A negative D-dimer test result in these patients essentially excludes the possibility of acute PE. A meta-analysis found that patients with a negative D-dimer and without a high pre-test probability of acute PE had a $0.14 \% 3$-month incidence of venous thromboembolism [38]. It is important to consider that the D-dimer can also be nonspecifically elevated in certain conditions, such as pregnancy, recent hospitalization, active neoplastic disease, and other chronic inflammatory states. A prospective longitudinal study of 100 patients with systemic lupus erythematosus with recurrent activity found that unexplained, persistent elevation of D-dimer levels, especially above $2.0 \mu \mathrm{g} /$ $\mathrm{mL}$, were associated with elevated risk of thrombosis [39]. Another study found that D-dimer levels in patients with estimated glomerular filtration rate of 30-60 $\mathrm{mL} / \mathrm{min}$ were $100 \%$ sensitive in ruling out acute PE although they were not specific enough to diagnose acute PE in this population [40]. Increased age has been associated with elevations in D-dimer concentrations, and a greater age-adjusted D-dimer threshold was found to be more specific (64\% versus 54\%) although less sensitive (93\% versus 98\%) in detecting acute $\mathrm{PE}$ in patients greater than 50 years old [41].

Patients with a high pre-test probability and occasionally those with intermediate pre-test probability require imaging to assess for acute PE. Computed tomography pulmonary angiography (CTPA) is usually the non-invasive imaging modality of choice. CTPA offers $83 \%$ sensitivity, $96 \%$ specificity, and $96 \%$ positive predictive value when diagnosing acute $\mathrm{PE}$ in patients considered to have a high pre-test probability [42]. A positive D-dimer test result also requires CTPA imaging to confirm or exclude acute PE [2, 32, 43].

The simplified Pulmonary Embolism Severity Index (sPESI) is a sensitive clinical prediction score used to risk stratify diagnosed acute PE patients [2, 44, 45]. This tool considers the variables of age $>80$ years old, history of cancer, chronic cardiopulmonary disease, heart rate $\geq 110$ beats per minute, systolic blood pressure $<100 \mathrm{mmHg}$, and arterial oxyhemoglobin saturation $<90 \%$. A patient is scored by receiving one point per variable present [46]. A score of 0 is considered low-risk with an associated 1.0-1.5\% 30-day mortality rate while a score of $\geq 1$ is considered high-risk with a $10.7-10.9 \%$ 30-day mortality rate [46, 47]. Stratifying diagnosed acute PE patients by prognostic risk can be helpful in identifying low-risk patients who may benefit from outpatient therapy and revealing higher risk patients who should receive inpatient treatment [48]. The 2019 European Society of Cardiology PE guidelines utilize the sPESI in addition to right ventricular strain on echocardiogram or CT, elevated troponin levels, and hemodynamic instability to classify patients with PE as low-, intermediate-low, intermediate-high, and high-risk PE [49]. Other prognostic scoring systems including the Bova and FAST scores utilize clinical, imaging, and laboratory data to estimate risk of early PE-associated mortality although their implications for clinical decision-making have not yet been elucidated [50-55].

\section{Endovascular treatment of acute PE}

The performance of endovascular therapy for acute PE treatment is evolving and gaining increasing interest. Endovascular treatment enables the removal of thromboembolic material from the pulmonary arterial system through

Table 1 Utility of tests in assessing acute PE

\begin{tabular}{ll}
\hline Test & Value \\
\hline Brain natriuretic peptide & Elevated levels associated with short-term mortality in hemodynamically stable patients with acute PE [22, 23] \\
Troponin & Elevated levels associated with greater in-hospital and short-term mortality in patients with acute PE [30, 31] \\
Electrocardiogram & Abnormalities associated with acute PE (nonspecific) [9, 24] and greater risk of death in patients with acute PE [25, \\
& $28]$ \\
\hline
\end{tabular}


catheter-directed lysis or aspiration thrombectomy. Endovascular treatment can be especially beneficial in patients with persistent hypotension or shock secondary to acute PE [56]. This treatment has the potential to improve right ventricular function by relieving elevated pulmonary vascular pressures and stabilizing hemodynamics [33].

A pulmonary embolism response team can help decide on the best therapy for a patient with acute PE [57-59]. Endovascular therapy can be considered in patients with contraindications to systemic thrombolysis who have submassive acute PE, evidenced by elevated troponin and brain natriuretic peptide, and right heart strain [33, 60, 61]. Endovascular therapy of acute PE usually involves placing a side hole infusion catheter through the thromboembolism and infusing tissue plasminogen activator (tPA). One mg of recombinant tPA per hour per catheter for a maximum total of $24 \mathrm{mg}$ is a typical dosage per the SEATTLE protocol [62]. The ULTIMA trial found that $10-20 \mathrm{mg}$ of recombinant tPA over $15 \mathrm{~h}$ in addition to unfractionated heparin reversed right ventricular dilatation at $24 \mathrm{~h}$ greater than unfractionated heparin alone [63]. These doses are lower than that used in systemic thrombolysis and are therefore thought to be associated with a lower risk of intracranial or other hemorrhage [33]. Aspiration thrombectomy with immediate removal of the offending thromboembolic material from the pulmonary arterial system is another endovascular treatment approach [33]. Aspiration thrombectomy is specifically beneficial for patients with contraindication to systemic or catheter directed thrombolysis secondary to elevated bleeding risk $[64,65]$.

The PERFECT registry prospectively enrolled 101 patients receiving catheter-directed therapy for acute PE in a multicenter registry. The study showed that catheterdirected therapy for acute PE decreased right-sided heart strain and pulmonary artery pressures without causing major bleeding events [66].

The OPTALYSE PE trial was a prospective, multicenter, parallel-group trial that included 101 patients with acute PE treated with ultrasound-assisted catheter-directed thrombolysis. The patients were randomized to 4 groups that varied by tPA dose (range of 4 to $12 \mathrm{mg}$ ) and infusion duration (range of 2 to $6 \mathrm{~h}$ ). The endpoints of RV/ LV diameter ratio and thromboembolic burden were significantly decreased in the treatment groups. Major bleeding occurred in only $4 \%$ of patients, and one intracranial hemorrhage event was attributed to ultrasound-assisted catheter-directed thrombolysis [67].

Studies have confirmed that endovascular treatment of acute PE is safe and effective with regard to short term hemodynamic stabilization. Additional studies should be done to assess the effect of catheter-directed therapy on long-term sequela of PE namely CTED and CTEPH with right ventricular failure.

\section{CT pulmonary angiography for pre-procedural planning}

Computed tomography pulmonary angiography (CTPA) is the current non-invasive imaging modality of choice to assess acute PE. Its strengths include its accuracy, speed of acquiring images, and widespread availability. CTPA may reveal alternative diagnoses contributing to a patient's presentation if acute PE is not visualized [68]. A prospective randomized trial assessing acute PE detection with CTPA compared to pulmonary angiography as gold standard found CTPA to have $91 \%$ accuracy [69]. CTPA also offers superior spatial resolution and multi-planar reconstruction [68]. Wide-array CT scanners can cover substantial length per rotation and are associated with reduced motion artifacts. Dual-energy CT can help to rule out acute segmental and sub-segmental PE by color-coding perfusion based on the iodine concentration (iodine or Z-effective mapping) [70].

Dual-energy CTPA involves using two distinct energy levels to capture the image [71]. This technique enables differentiation between tissues with similar attenuation values using various processing techniques such as iodine maps, virtual non-contrast (VNC) and virtual monochromatic images (VMI). Iodine maps accentuate iodine-containing tissue and improve the sensitivity of perfusion defects. VNC images imitate non-contrast images by virtually removing iodine and can be used for calcium scoring or as a substitute for true non-contrast images. VMI imitate an X-ray beam with one energy level and are created by a linear combination of basis pair images in different proportions. VMI can decrease artifacts and thereby improve specificity [71, 72]. Lung perfusion maps can be derived from iodine maps (Figs. 1 and 2) [33]. A pulmonary perfused blood volume (PBV) map color codes parenchymal tissue by iodine concentration $[73,74]$. Perfusion defects are normalized to the vascular iodine concentration, and areas that do not fall within this attenuation range are excluded. Hence, lung abnormalities appear dark on PBV maps. PBV maps can also be merged with conventional CT images to better analyze the lungs' form and function $[75,76]$.

Dual-energy CT can salvage suboptimal studies and reduce the contrast exposure to patients. This is accomplished by using low-energy VMI less than $70 \mathrm{keV}$, which exhibits greater photoelectron attenuation and thus greater contrast [77]. As many as $10 \%$ of regularly acquired CTPA studies are non-diagnostic, and $40 \%$ of those are caused by poor contrast enhancement [78]. While poorly enhanced studies often require repeat contrast doses and repeat scanning with associated radiation exposure, low energy VMI 


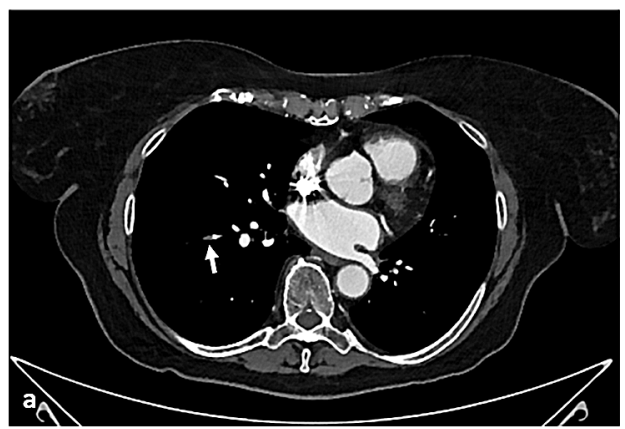

Fig. 1 80-year-old female with known ANCA-negative, mediumsize-vessel vasculitis presenting with progressive dyspnea over a period of 4 weeks. a Dual-energy CTPA demonstrates filling defects of several subsegmental arteries, one of them illustrated in this axial plane (arrow). b Z-effective map of the dual-energy CTPA demonstrating iodine distribution with blue colors representing high iodine

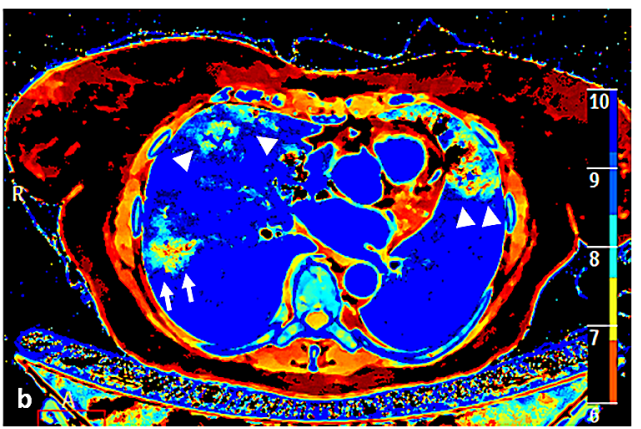

concentration and yellow and red colors representing low iodine concentration. This axial plane at the same level shows a wedge-shaped area of low iodine concentration (arrows) corresponding to an area of reduced perfusion caused by the embolus seen in a. Further perfusion defects can be appreciated on the same plane (arrowheads) corresponding to more emboli not detected with regular CTPA imaging
Fig. 2 64-year-old male with hepatocellular carcinoma. a Dual-energy CTPA demonstrates filling defects of several subsegmental arteries, one of them illustrated in this axial plane (arrow). b Z-effective map of the dual-energy CTPA illustrates a wedge-shaped area of low iodine concentration at the same level corresponding to an area of reduced perfusion (arrow)
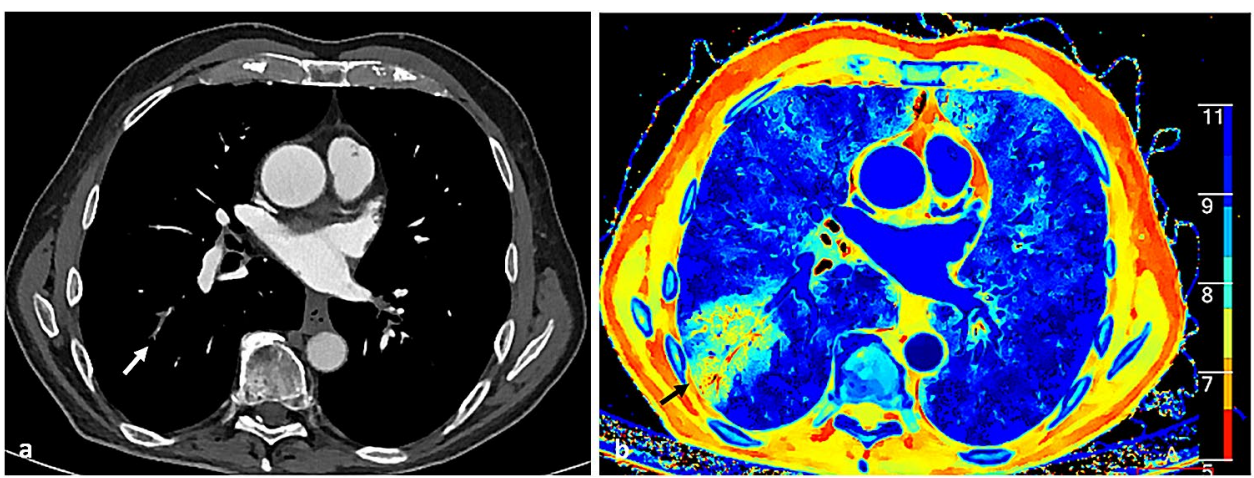

avoids this by virtually increasing vessel attenuation and contrast-to-noise ratio (CNR). The subjective image quality was found to be best at $70 \mathrm{keV}$ VMI when compared to polyenergetic images in one study [79]. Another study found that $60 \mathrm{keV}$ produced the greatest CNR and sound-to-noise ratio (SNR) while maintaining image quality and using $35 \%$ of the typical iodine concentration [80]. Dual-energy CT has also been found to produce high SNR, and CNR while requiring only $40 \%$ of the typical iodine based contrast agent dose [81].

High-energy VMI has the ability to reduce artifacts, with $100 \mathrm{keV}$ producing the least artifacts [80]. Beam hardening artifacts originating from dense contrast in the superior vena cava is especially reduced with high-energy VMI [71]. The high-pitch helical mode of dual-source scanners also results in diagnostic image quality by requiring decreased breath hold duration and thus leading to reduced motion artifacts. This mode is also associated with decreased radiation and contrast exposure to the patient [82]. A retrospective study of ultra-high-pitch dual-source CTPA in patients with suspected PE found that a reduced voltage $(100 \mathrm{kV})$ compared to a standard voltage $(120 \mathrm{kV})$ resulted in significantly reduced radiation dose, greater subjective image quality, and improved SNR and CNR. Diagnostic agreement between readers for the reduced voltage was very high $(\kappa=0.891)$ [83]. Iterative reconstructive algorithms can further reduce patients' radiation exposure [84]. A retrospective study of 4011 patients divided into three groups differentiated by CT optimization technique found that iterative reconstruction resulted in a significant radiation dose reduction of 16-31\% when combined with automated tube current modulation. The same study found that iterative reconstruction improved levels of objective noise [85]. Another study found that iterative model reconstruction could reduce radiation doses up to $50 \%$ while preserving image quality [86].

CTPA can be helpful in the planning stages of endovascular therapy for acute PE. In the coronal orientation, it can reveal both the number and distribution of emboli. During 

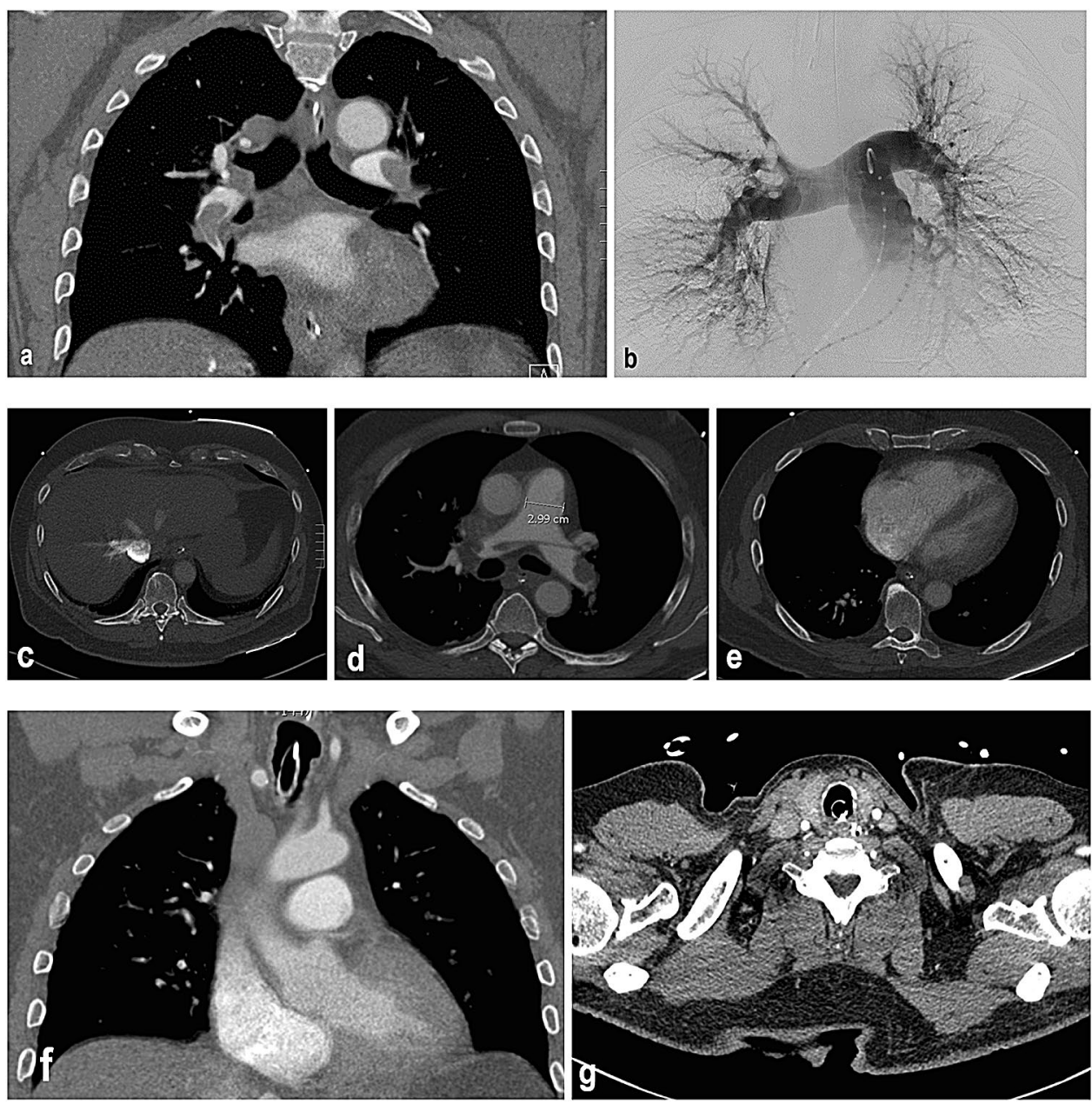

Fig. 3 69-year-old male with a massive pulmonary embolism status post cardiac arrest with ROSC achieved after CPR. a Coronal view CTPA showing bilateral pulmonary artery emboli extending into segmental branches. b Digital subtraction angiography of pulmonary arteries via right common femoral vein access with 5 Fr flush pigtail drainage catheter in main pulmonary artery showing bilateral acute PE, predominantly on the right side. Correlation between coronal CTPA and DSA images is helpful to determine extend of disease. c-e Signs of right heart strain and acute PE on axial CTPA imaging

the procedure coronal reconstruction can be correlated to CTPA images to ensure proper catheter position within the acute thromboembolic material. Right heart strain is a common pathology associated with acute PE, and CTPA reveals signs of right heart strain including increased RV/ LV diameter ratio of 0.9 or greater, interventricular septal bowing towards the left ventricle, contrast reflux into the hepatic vein as well as inferior vena cava (IVC), and increased IVC diameter compared to baseline [87]. Capturing the pulmonary artery size allows its comparison to prior CTs and may show an acute enlargement secondary to PE. CTPA also enables characterization of the venous anatomy including proximal IVC and the patency of the central veins. including reflux of contrast into hepatic veins and IVC (c), acute dilatation of main pulmonary artery (d) as well as RV to LA ratio of more than 1 with straightening of the interventricular septum. $\mathbf{f}$ and g are representative coronal and axial CTPA slices showing patent SVC and patent bilateral internal jugular veins. This information can be gained from the CTPA and is helpful for procedure planning purposes, particularly if the endovascular treatment approach will be pursued via internal jugular vein access

This information is important for access planning purposes (Figs. 3 and 4).

Dual-energy CT perfusion images simulate true perfusion by allowing the comparison of a tissue's innate physical density with its enhancement during acquisition [88]. These perfusion images do not require changing the CTA protocol, which confers the benefits of not requiring additional radiation or contrast and thereby minimizing motion misregistration from repeated acquisitions [88]. The resulting images correlate well with those of scintigraphic perfusion images. PBV images have shown modest correlation with lung scintigraphy in CTEPH patients [89]. One study of dual-energy CT perfusion images compared to scintigraphy showed $96 \%$ sensitivity and $76 \%$ specificity [90]. Another 
Fig. 4 48-year-old female presenting with severe shortness of breath and chest pain. The patient has a history of metastatic breast cancer. a-c Coronal CTPA slices showing pulmonary embolus in right and left pulmonary arteries extending into multiple segmental branches. d RV to LV of 1.0 suggestive of right heart strain. e In this case there is no significant contrast reflux into suprahepatic inferior vena cava and / or hepatic veins
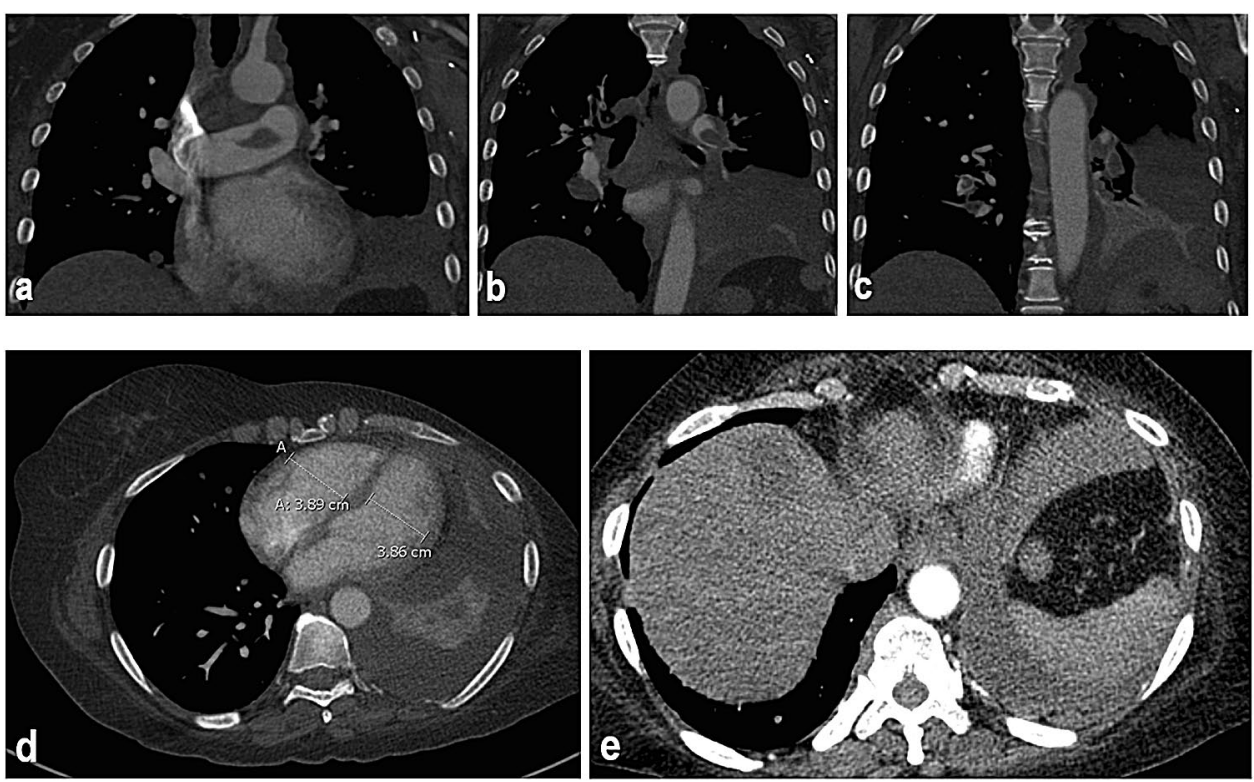

study comparing dual-energy CT perfusion images to scintigraphy at the segmental level showed $83 \%$ sensitivity and 99\% specificity [91].

Acute and chronic PE present differently on CTPA. Acute PEs are typically located at vessel bifurcations and may completely or partially obstruct pulmonary vasculature $[13,32]$. A complete obstruction is characterized on CTPA as a hypoattenuating contrast defect occupying a vessel's entire lumen and can be seen in acute PE. The vessel diameter at the obstruction level is usually maintained or increased slightly. Partial obstructions may be located centrally (indicative of acute PE) or eccentrically (indicative of chronic PE). Complete obstruction in the setting of acute PE can cause distal infarcts that appear on CTPA as a triangular subpleural consolidation or ground-glass opacity with fine reticular changes.

Chronic PE appearance varies based on the extent of obstruction and degree of chronicity. Complete obstruction presents as a lack of contrast distal to the obstruction and an immediate narrowing of the vessel diameter. Partial obstruction is characterized by a narrow diameter and partially attenuated vessel or dilation distal to the obstruction. Chronic nonobstructive PE manifests as a narrow vessel, irregular intima, and intraluminal bands and webs [13]. The abrupt narrowing of vessels is caused by recanalization of the thrombus. Thrombi along a vessel wall can become endothelialized or "laminated" and will appear as an irregular intimal surface contour that forms obtuse angles with the contrast column. Laminated thrombi often present with calcifications. Bands are linear structures that run along the long axis of a vessel and may appear in the setting of chronic PE. Webs are networks of bands that are often found at vessel bifurcations in chronic PE and are associated with distal neovasculature [13, 92, 93].

Chronic PE raises vascular resistance and is characterized by dilation of the central pulmonary arteries secondary to pulmonary hypertension. The main pulmonary artery (MPA) diameter at the level of its bifurcation lateral to the ascending aorta is used to assess for the presence of pulmonary hypertension. MPA diameters greater than $28 \mathrm{~mm}$ in men and $27 \mathrm{~mm}$ in women are typical predictive cut-offs for pulmonary hypertension [94]. A greater cut-off of $31.6 \mathrm{~mm}$ has also been suggested [95]. A MPA-to-ascending aorta diameter ratio greater than 1 is also a reliable method of assessing for pulmonary hypertension. This measurement offers $70 \%$ sensitivity, $92 \%$ specificity, $96 \%$ positive predictive value, and $52 \%$ negative predictive value [96]. In CTEPH pulmonary arteries can appear tortuous with calcified walls [13].

Chronic PE can present with right ventricular hypertrophy evidenced by ventricular wall thickness greater than $4 \mathrm{~mm}$ [13]. Development of right ventricular dysfunction causes right ventricular enlargement [87]. Right ventricular enlargement can dilate the tricuspid valve annulus leading to tricuspid regurgitation. The lung parenchyma distal to the occlusion or stenosis of chronic PE presents with a mosaic perfusion pattern that appears as well-demarcated hypoattenuated tissue with narrow vasculature contrasted with the hyperattenuated tissue being in possession of larger vasculature of well-perfused lung parenchyma. Areas of infarction can resolve in the long-term to form peripheral nodules, cavities, subpleural scars, or irregular peripheral lines [13].

Right heart strain is important to recognize on CTPA and has characteristic signs on imaging as previously described (Fig. 5). A RV/LV diameter ratio $\geq 0.9$ is predictive for poor clinical outcomes after acute PE [43, 97, 98]. A study of 457 

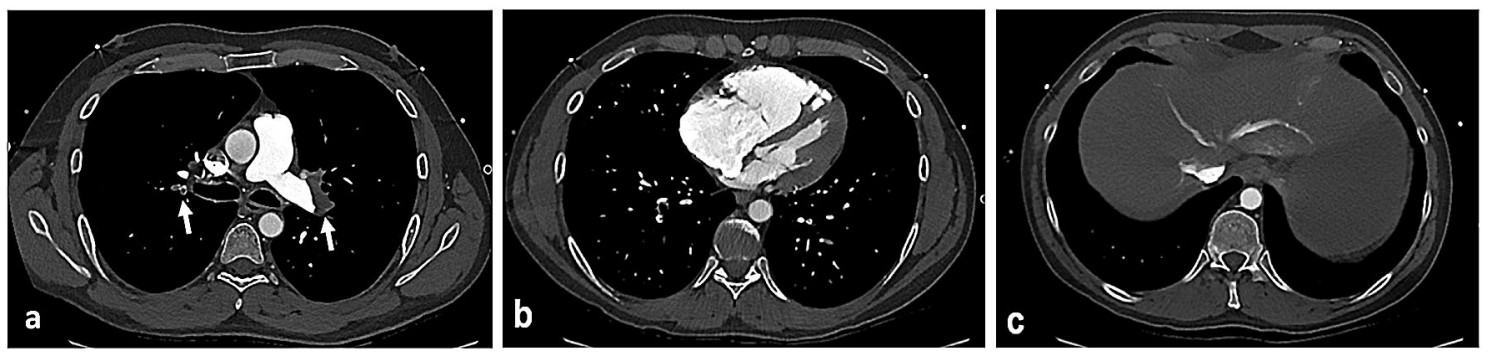

Fig. 5 45-year-old male patient with acute dyspnea. a CTPA shows emboli in the left pulmonary artery bifurcation and the lower lobe segmental artery on the right side (arrows) b Significant enlargement of the right ventricle with a nearly inversed configuration of the inter-

patients found that $\mathrm{RV} / \mathrm{LV}$ diameter ratio $\geq 0.9$ was an accurate predictor of in-hospital death or clinical deterioration [87]. A meta-analysis found that right ventricular dilation is associated with elevated 30-day mortality, increased risk of death from PE, and increased 3-month mortality rate (OR 4.65) [99].

Ten to fifteen percent of acute PEs cause infarction of the lung. This appears as a wedge-shaped peripheral lung opacity, often referred to as a "Hampton hump," on CTPA. These opacities can have a central ground glass appearance [33].

CTPA has its inherent limitations secondary to artifacts. Patient breathing causes motion artifacts that particularly affects the lower lung zones. Cardiac motion may also disrupt the pericardial zone image quality. Attenuation along a vessel may be disturbed by beam hardening artifacts from contrast originating from abutting vasculature, wires, or medical devices [33]. Studies have found $0.5 \%$ to $12.1 \%$ of CTPA studies to be non-diagnostic [78, 100-112].

\section{Ventilation/perfusion scan}

Ventilation/Perfusion (V/Q) scanning was the mainstay diagnostic method for acute PE before the development of newer CT techniques [113]. This imaging modality can be valuable when estimating the probability of an acute PE [114, 115]. Patients who are pregnant, have renal failure or contrast allergies, or cannot fit into a CT scanner also particularly benefit from V/Q scans. V/Q scans expose patients' breasts to 50 times less radiation compared to $\mathrm{CT}$, which helps to reduce breast cancer risk in young women [116-118]. The fetal radiation dose associated with V/Q scans has been estimated to be 3.4-6 times higher than the fetal radiation dose associated with low-dose CTPA. While V/Q scans are associated with a greater fetal risk for childhood cancer compared to CTPA, their aggregated radiation risk for a pregnant patient and her fetus is lower compared to CTPA. This difference in aggregated radiation risk increases with greater maternal body mass index and increased gestational age and ventricular septum, consistent with right heart strain. c A less specific, but also typical sign of right heart strain is the reflux of contrast material into the inferior vena cava and hepatic veins

suggests that V/Q scans are more dose-efficient than CTPA for pregnant patients $[119,120]$.

V/Q scan is the indicated diagnostic test for acute PE in pregnant patients with a normal chest radiograph. A retrospective study of 304 pregnant or postpartum women suspected to have an acute PE found that the patients with a normal chest radiograph were more likely to have a diagnostic image from V/Q scanning compared to CTPA. Various retrospective studies have found that $75-93 \%$ of V/Q scans of pregnant patients suspected to have acute PE resulted in diagnostic studies [11, 121-127]. CTPA has also been associated with a significantly higher incidence of sub-optimal studies for assessing acute PE in pregnant patients compared to age-matched non-pregnant controls [128]. This further contributes to the evidence supporting V/Q scan as the diagnostic test of choice in pregnant patients with a normal chest radiograph who are suspected to have acute $\mathrm{PE}$.

V/Q scans make use of ventilation agents labeled with technetium-99 m (Tc-99 m) or radioactive noble gases such as Xenon-133 or Krypton-81 m. Technetium-99 m-labeled diethylenetriaminepentaacetic acid (DTPA) is the most commonly used agent [115].

Tc-99 m-labeled macro-aggregated albumin (MAA) is injected intravenously to image perfusion for V/Q scans. The patient is positioned upright for the scan, which acquires multiple planar images. Single-photon emission computed tomography (SPECT)/CT using a low-dose CT technique may also be performed to better localize abnormalities [115].

The perfusion scan may be acquired before or after the ventilation scan. Imaging perfusion first guides the projection used for ventilation scans using Xenon-133. A normal perfusion scan can preclude the need for a ventilation scan, which is particularly valuable for patients requiring minimization of radiation exposure such as the pregnant patient population. Some authors have proposed primarily using perfusion-only scintigraphy in the diagnostic assessment of acute pulmonary embolism to reduce potential viral transmission by aerosolization in the setting of the current global COVID-19 pandemic [129]. 
V/Q scans are interpreted with a corresponding chest radiograph taken within $12-24 \mathrm{~h}$ of the scan. Acute PE is often visualized as peripheral wedge-shaped perfusion defects in a lobar, segmental, or sub-segmental distribution in the absence of an associated ventilation abnormality. This mismatched defect can also be found with other conditions including malignancy, vascular abnormalities, vasculitis, veno-occlusive disease, and mediastinal lymphadenopathy and therefore a chest radiograph is valuable for comparison purposes [43].

The most commonly used criteria for interpretation of V/Q scans for acute PE are the modified Prospective Investigation of Pulmonary Embolism Diagnosis (PIOPED) II and prospective investigative study of acute pulmonary embolism diagnosis (PISAPED) criteria $[115,130]$. Patients can be categorized as high probability, intermediate probability, very low probability, normal, and non-diagnostic using the modified PIOPED II criteria. A normal scan is characterized by diffusely homogenous radiotracer activity in the lungs on ventilation and perfusion scans while a high probability scan is characterized by two or more large segmental mismatch defects or segmental defect equivalents. A very low probability scan will appear as a non-segmental defect [115].

The PIOPED II criteria have found V/Q scans to have $85 \%$ sensitivity and $93 \%$ specificity for acute PE, and the PISAPED criteria found to have $80 \%$ sensitivity and $97 \%$ specificity for diagnosing PE $[113,130]$. Utilizing SPECT can improve V/Q scan sensitivity and specificity by enabling three-dimensional visualization of the lung. The addition of SPECT has been found to offer a $97 \%$ sensitivity and $91 \%$ specificity for diagnosing acute PE [131].

\section{Magnetic resonance angiography}

Magnetic resonance angiography (MRA) is an evolving imaging modality that can be used for evaluating the possibility of acute PE in certain patient populations. Pregnant or young patients may benefit from MRA instead of CTPA if acute $\mathrm{PE}$ is suspected due to the lack of ionizing radiation exposure. Patients with history of anaphylactoid reactions to iodine contrast media and those with chronic kidney disease may benefit from MRA as well [132].

MRA assessment for acute PE includes axial and coronal static steady-state free precession (SSFP) sequences, contrast-enhanced 3D MRA using T1-weighted GRE sequences, and an optional time-resolved contrast-enhanced 3D MRA for dynamic perfusion imaging [133].

The static SSFP sequences are acquired during free breathing or inspiratory breath-hold. These sequences can detect acute PE without the use of IV contrast due to the bright blood signal (Fig. 6). A non-contrast MRA is especially valuable for pregnant patients who ideally should not receive gadolinium contrast $[33,134]$. The 3D-balanced
Fig. 6 62-year-old female patient with acute dyspnea. a Static SSFP sequence acquired in coronal orientation shows a filling defect in the right upper lobe artery (white arrows). b and c Contrast-enhanced 3D MRA acquired in coronal orientation in the pulmonary arterial phase (b) and $25 \mathrm{~s}$ later (c) confirms the findings of the SSFP sequence (white arrows). d Time-resolved, contrast-enhanced 3D MRA demonstrates a corresponding perfusion defect in the right upper lobe (black arrows) as well as further perfusion defects in the right and left basal segments (black arrow heads, corresponding thromboemboli not illustrated in this figure)
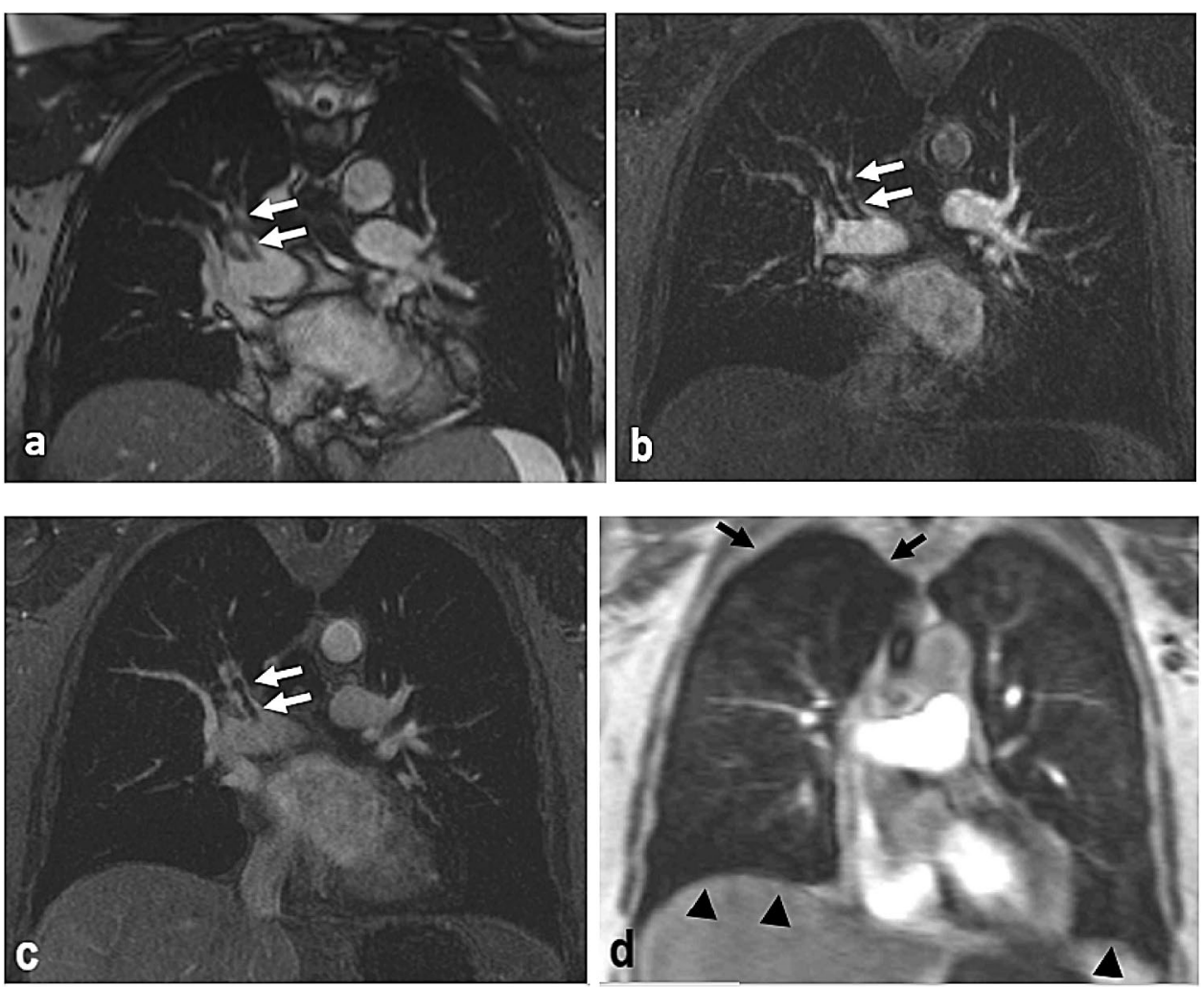
SSFP sequence is commonly used. It creates T2/T1 weighting with radiofrequency pulse phase alteration and gradient echo refocusing that results in a steady state. A long T2 with high signal contrast causes blood to appear bright which facilitates thrombus detection [134]. This sequence offers high sensitivity for field heterogeneity and requires only a short repetition time to minimize artifacts [135]. Balanced SSFP has also been shown to provide fast, accurate measurement of pulmonary artery diameters [136]. Arterial spin labelling makes use of slice selective acquisition with repeat imaging after an initial inversion pulse. It can be particularly valuable when combined with faster sequences. This technique acquires an image with upstream blood tagged by an inversion radiofrequency pulse and another image without such tagging [134]. A subtraction between these images depict signal solely from the tagged blood and helps with visualizing vessels and tissue perfusion [137]. The fresh blood imaging technique makes use of the EKG-gated 3D partial Fourier fast spin echo technique. This sequence makes arterial blood in systole appear dark because of flow void and in diastole appear bright because of slows flow. Veins produce some intensity in systole and diastole due to slow flow [134]. An image with high signal intensity in the arteries and low signal intensity in the veins can be created by subtracting the systolic and diastolic images [137]. However this sequence is not commonly used to diagnose PE due to its susceptibility to misregistration [134].

Contrast-enhanced 3D MRA offers high spatial resolution of the pulmonary vasculature (Fig. 7). This technique utilizes intravenous gadolinium contrast that causes $\mathrm{T} 1$ shortening in adjacent tissues leading to a high signal intensity in MRA images [134]. Coronal images are typically acquired during inspiratory breath-holds. Usually pre-contrast images for subtraction purposes are obtained, followed by arterial phase images, and late arterial phase images [133]. Timing the acquisition accurately achieves high SNR and allows separation of the arterial and venous phase [134]. The time at which the pulmonary arteries show maximum contrast enhancement is assessed utilizing a bolus-tracking technique (Fig. 6) [33]. Bolus-tracking techniques include utilization of dynamic low resolution magnetic resonance fluoroscopy and starting the acquisition just before contrast enters the pulmonary arterial tree. One could also utilize a test bolus injection of 1 to $2 \mathrm{~mL}$ of contrast to assess the time required for the contrast to reach the target vasculature [134].

3D T1-weighted spoiled gradient echo sequence acquisition uses values of $\mathrm{TR}=2.5-3 \mathrm{~ms}, \mathrm{TE}=1.0-1.5 \mathrm{~ms}$, flip angle $=30-40^{\circ}$, matrix $=40 \times 192 \times 256, \mathrm{FOV}=460 \mathrm{~mm}$, and parallel imaging factor $(R)=2$ [138]. Acquiring data in an oval area of $\mathrm{k}$-space and zero-filling corners enables isotropic spatial resolution. Fractional echo read-out can reduce TE and TR. This sequence can achieve $2 \mathrm{~mm}$ spatial resolution in phase encoded direction and $1.5 \mathrm{~mm}$ spatial resolution in frequency encoded direction [139]. Timeresolved contrast-enhanced 3D MRA is performed with repeated rapid volumetric sequences that sample the center of the k-space more frequently than the periphery [140, 141]. Data that are missing at each time point are shared between $\mathrm{k}$-spaces by applying a variety of techniques [142-145]. The images are captured during shallow breathing after the first
Fig. 7 69-year-old male with acute dyspnea. $\mathbf{a}$ and $\mathbf{b}$ Contrast-enhanced 3D MRA acquired in coronal orientation demonstrates filling defects, among others a long filling defect in the left lower lobe artery with a "railway sign" (a, white arrows) and the filling defect is shown as a "polo mint sign" on the axial reconstruction of the same data set (b, white arrow). c Time-resolved, contrast-enhanced 3D MRA reveals extensive wedge-shaped perfusion defects in the left upper and lower lobes (black arrows)
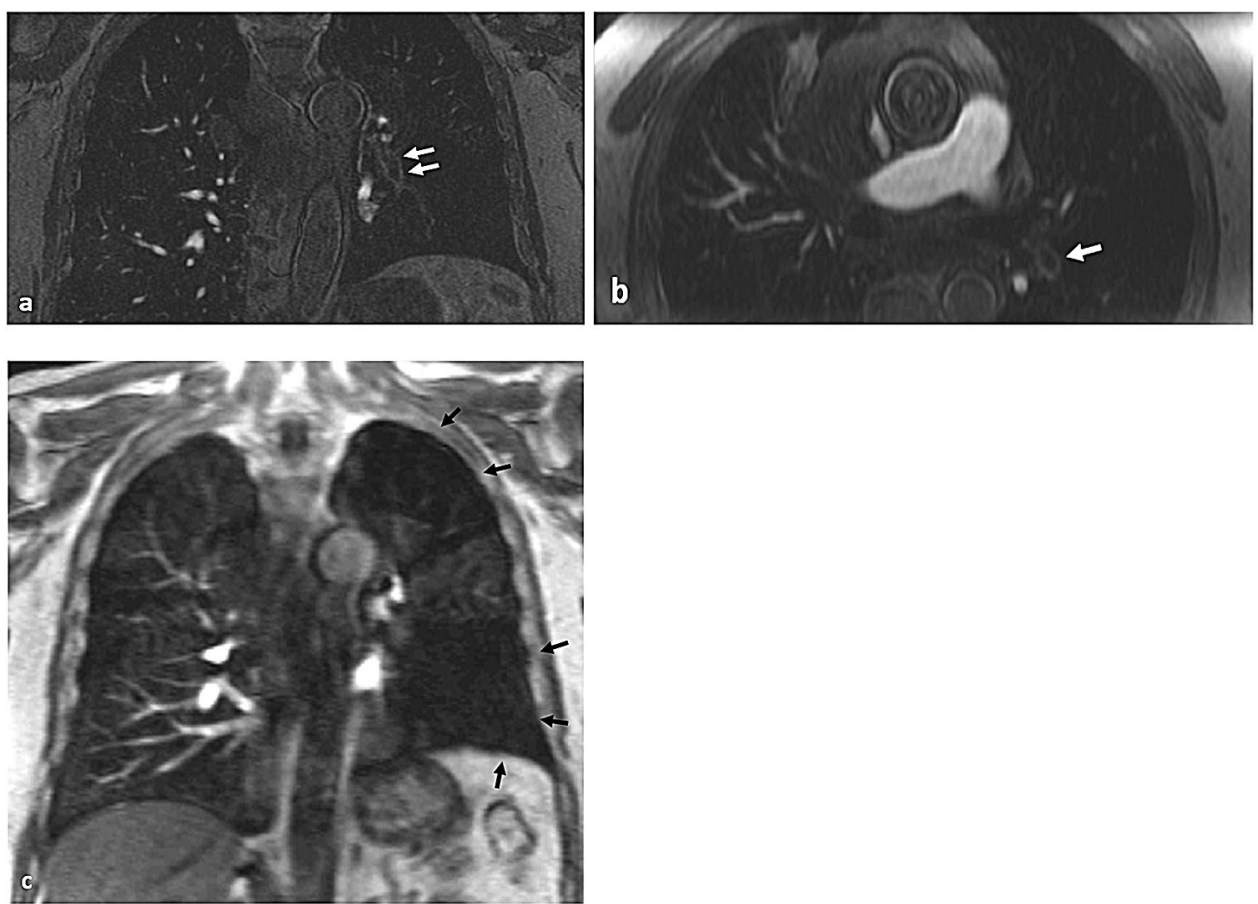
pass of a gadolinium contrast bolus. There is some evidence that time-resolved contrast-enhanced MRA during patient free-breathing may achieve accurate diagnoses and vessel measurements, which could make this sequence especially beneficial in the pediatric population and in patients with severe dyspnea [146]. When using power injectors this technique is particularly helpful for visualizing perfusion defects when pursuing subtraction images (Fig. 6d and 7c) [147, 148].

\section{Conclusion}

Imaging plays a crucial role in the assessment of acute pulmonary embolism (PE) prior to endovascular intervention. CTPA is the modality of choice for the diagnosis of acute PE given its availability as well as excellent sensitivity and specificity. This imaging modality facilitates detection and characterization of the extent of the pulmonary embolus (particularly helpful in coronal view to correlate with angiography in the case of endovascular treatment) and enables assessment of right heart strain. Further, CTPA allows evaluation of the access route for endovascular interventions to ensure patency of the central venous system. MRI offers a limited role in the diagnosis of acute PE in certain patient populations, specifically in pregnant patients. In current clinical practice 3D MRA largely relies on Gadolinium based contrast administration for diagnosis of acute PE. However, non-contrast MRA sequences such as SSFP are evolving for the assessment of the pulmonary arterial vasculature.

Funding Not applicable.

\section{Compliance with ethical standards}

Conflict of interest The authors declares that they have no conflict of interest.

\section{References}

1. Raja AS, Greenberg JO, Qaseem A, Denberg TD, Fitterman N, Schuur JD, for the Clinical Guidelines Committee of the American College of Physicians (2015) Evaluation of patients with suspected acute pulmonary embolism: best practice advice from the Clinical Guidelines Committee of the American College of Physicians. Ann Intern Med 163:701. https://doi.org/10.7326/ M14-1772

2. Konstantinides SV, Torbicki A, Agnelli G, Danchin N, Fitzmaurice D, Galiè N, Gibbs JSR, Huisman MV, Humbert M, Kucher N, Lang I, Lankeit M, Lekakis J, Maack C, Mayer E, Meneveau N, Perrier A, Pruszczyk P, Rasmussen LH, Schindler TH, Svitil P, Vonk Noordegraaf A, Zamorano JL, Zompatori M, Task Force for the Diagnosis, and Management of Acute Pulmonary Embolism of the European Society of Cardiology (ESC) (2014)
2014 ESC guidelines on the diagnosis and management of acute pulmonary embolism. Eur Heart J 35:3033-3069. https://doi. org/10.1093/eurheartj/ehu283

3. Alotaibi GS, Wu C, Senthilselvan A, McMurtry MS (2016) Secular trends in incidence and mortality of acute venous thromboembolism: the AB-VTE Population-Based Study. Am J Med 129:879.e19-25. https://doi.org/10.1016/j.amjme d.2016.01.041

4. Horlander KT, Mannino DM, Leeper KV (2003) Pulmonary embolism mortality in the United States, 1979-1998: an analysis using multiple-cause mortality data. Arch Intern Med 163:17111717. https://doi.org/10.1001/archinte.163.14.1711

5. Silverstein MD, Heit JA, Mohr DN, Petterson TM, O'Fallon WM, Melton LJ (1998) Trends in the incidence of deep vein thrombosis and pulmonary embolism: a 25-year population-based study. Arch Intern Med 158:585-593. https://doi.org/10.1001/archi nte.158.6.585

6. Naess IA, Christiansen SC, Romundstad P, Cannegieter SC, Rosendaal FR, Hammerstrøm J (2007) Incidence and mortality of venous thrombosis: a population-based study. J Thromb Haemost 5:692-699. https://doi.org/10.1111/j.1538-7836.2007.02450.x

7. Tagalakis V, Patenaude V, Kahn SR, Suissa S (2013) Incidence of and mortality from venous thromboembolism in a real-world population: the Q-VTE Study Cohort. Am J Med 126:832.e1321. https://doi.org/10.1016/j.amjmed.2013.02.024

8. Stein PD, Beemath A, Matta F, Weg JG, Yusen RD, Hales CA, Hull RD, Leeper KV, Sostman HD, Tapson VF, Buckley JD, Gottschalk A, Goodman LR, Wakefied TW, Woodard PK (2007) Clinical characteristics of patients with acute pulmonary embolism: data from PIOPED II. Am J Med 120:871-879. https://doi. org/10.1016/j.amjmed.2007.03.024

9. Stein PD, Saltzman HA, Weg JG (1991) Clinical characteristics of patients with acute pulmonary embolism. Am J Cardiol 68:1723-1724. https://doi.org/10.1016/0002-9149(91)90339-m

10. Stein PD, Terrin ML, Hales CA, Palevsky HI, Saltzman HA, Thompson BT, Weg JG (1991) Clinical, laboratory, roentgenographic, and electrocardiographic findings in patients with acute pulmonary embolism and no pre-existing cardiac or pulmonary disease. Chest 100:598-603. https://doi.org/10.1378/chest .100 .3 .598

11. Investigators PIOPED (1990) Value of the ventilation/perfusion scan in acute pulmonary embolism. Results of the prospective investigation of pulmonary embolism diagnosis (PIOPED). JAMA 263:2753-2759. https://doi.org/10.1001/jama.1990.03440 200057023

12. Burrowes KS, Clark AR, Tawhai MH (2011) Blood flow redistribution and ventilation-perfusion mismatch during embolic pulmonary arterial occlusion. Pulm Circ 1:365-376. https://doi. org/10.4103/2045-8932.87302

13. Ruggiero A, Screaton NJ (2017) Imaging of acute and chronic thromboembolic disease: state of the art. Clin Radiol 72:375388. https://doi.org/10.1016/j.crad.2017.02.011

14. Marcus JT, Gan CT-J, Zwanenburg JJM, Boonstra A, Allaart CP, Götte MJW, Vonk-Noordegraaf A (2008) Interventricular mechanical asynchrony in pulmonary arterial hypertension: leftto-right delay in peak shortening is related to right ventricular overload and left ventricular underfilling. J Am Coll Cardiol 51:750-757. https://doi.org/10.1016/j.jacc.2007.10.041

15. Hepburn-Brown M, Darvall J, Hammerschlag G (2019) Acute pulmonary embolism: a concise review of diagnosis and management. Intern Med J 49:15-27. https://doi.org/10.1111/imj.14145

16. Pollack CV, Schreiber D, Goldhaber SZ, Slattery D, Fanikos J, O'Neil BJ, Thompson JR, Hiestand B, Briese BA, Pendleton RC, Miller CD, Kline JA (2011) Clinical characteristics, management, and outcomes of patients diagnosed with acute pulmonary embolism in the emergency department: initial report 
of EMPEROR (Multicenter Emergency Medicine Pulmonary Embolism in the Real World Registry). J Am Coll Cardiol 57:700-706. https://doi.org/10.1016/j.jacc.2010.05.071

17. Miniati M, Prediletto R, Formichi B, Marini C, Di RICCOG, Tonelli L, Allescia G, Pistolesi M (1999) Accuracy of Clinical Assessment in the Diagnosis of Pulmonary Embolism. Am J Respir Crit Care Med 159:864-871. https://doi.org/10.1164/ajrcc m.159.3.9806130

18. Stein PD, Goldhaber SZ, Henry JW, Miller AC (1996) Arterial blood gas analysis in the assessment of suspected acute pulmonary embolism. Chest 109:78-81. https://doi.org/10.1378/chest .109.1.78

19. Stein PD, Goldhaber SZ, Henry JW (1995) Alveolar-arterial oxygen gradient in the assessment of acute pulmonary embolism. Chest 107:139-143. https://doi.org/10.1378/chest.107.1.139

20. Söhne M, Ten Wolde M, Boomsma F, Reitsma JB, Douketis JD, Büller HR (2006) Brain natriuretic peptide in hemodynamically stable acute pulmonary embolism. J Thromb Haemost 4:552556. https://doi.org/10.1111/j.1538-7836.2005.01752.x

21. Kiely DG, Kennedy NS, Pirzada O, Batchelor SA, Struthers AD, Lipworth BJ (2005) Elevated levels of natriuretic peptides in patients with pulmonary thromboembolism. Respir Med 99:1286-1291. https://doi.org/10.1016/j.rmed.2005.02.029

22. Lankeit M, Jiménez D, Kostrubiec M, Dellas C, Kuhnert K, Hasenfuß G, Pruszczyk P, Konstantinides S (2014) Validation of $\mathrm{N}$-terminal pro-brain natriuretic peptide cut-off values for risk stratification of pulmonary embolism. Eur Respir J 43:16691677. https://doi.org/10.1183/09031936.00211613

23. Coutance G, Cauderlier E, Ehtisham J, Hamon M, Hamon M (2011) The prognostic value of markers of right ventricular dysfunction in pulmonary embolism: a meta-analysis. Crit Care 15:R103. https://doi.org/10.1186/cc10119

24. Co I, Eilbert W, Chiganos T (2017) New electrocardiographic changes in patients diagnosed with pulmonary embolism. J Emerg Med 52:280-285. https://doi.org/10.1016/j.jemer med.2016.09.009

25. Shopp JD, Stewart LK, Emmett TW, Kline JA (2015) Findings from 12-lead electrocardiography that predict circulatory shock from pulmonary embolism: systematic review and meta-analysis. Acad Emerg Med 22:1127-1137. https://doi.org/10.1111/ acem.12769

26. Rodger M, Makropoulos D, Turek M, Quevillon J, Raymond F, Rasuli P, Wells PS (2000) Diagnostic value of the electrocardiogram in suspected pulmonary embolism. Am J Cardiol 86(807-809):A10. https://doi.org/10.1016/s0002-9149(00)01090 $-0$

27. Ferrari E, Imbert A, Chevalier T, Mihoubi A, Morand P, Baudouy M (1997) The ECG in pulmonary embolism. Predictive value of negative $\mathrm{T}$ waves in precordial leads- 80 case reports. Chest 111:537-543. https://doi.org/10.1378/chest.111.3.537

28. Geibel A, Zehender M, Kasper W, Olschewski M, Klima C, Konstantinides SV (2005) Prognostic value of the ECG on admission in patients with acute major pulmonary embolism. Eur Respir J 25:843-848. https://doi.org/10.1183/09031936.05.00119704

29. Elliott CG, Goldhaber SZ, Visani L, DeRosa M (2000) Chest radiographs in acute pulmonary embolism. Results from the International Cooperative Pulmonary Embolism Registry. Chest 118:33-38. https://doi.org/10.1378/chest.118.1.33

30. Piazza G (2013) Submassive pulmonary embolism. JAMA 309:171-180. https://doi.org/10.1001/jama.2012.164493

31. Becattini C, Vedovati MC, Agnelli G (2007) Prognostic value of troponins in acute pulmonary embolism: a meta-analysis. Circulation 116:427-433. https://doi.org/10.1161/CIRCULATIO NAHA.106.680421
32. Tanabe Y, Landeras L, Ghandour A, Partovi S, Rajiah P (2018) State-of-the-art pulmonary arterial imaging-part 1. VASA 47:345-359. https://doi.org/10.1024/0301-1526/a000708

33. Palm V, Rengier F, Rajiah P, Heussel CP, Partovi S (2020) Acute pulmonary embolism: imaging techniques, findings, endovascular treatment and differential diagnoses. Fortschr Röntgenstr 192:38-49. https://doi.org/10.1055/a-0900-4200

34. Ceriani E, Combescure C, Le Gal G, Nendaz M, Perneger T, Bounameaux H, Perrier A, Righini M (2010) Clinical prediction rules for pulmonary embolism: a systematic review and metaanalysis. J Thromb Haemost 8:957-970. https://doi.org/10.111 1/j.1538-7836.2010.03801.x

35. Le Gal G, Righini M, Roy P-M, Sanchez O, Aujesky D, Bounameaux H, Perrier A (2006) Prediction of pulmonary embolism in the emergency department: the revised Geneva score. Ann Intern Med 144:165-171. https://doi.org/10.7326/0003-4819144-3-200602070-00004

36. Klok FA, Mos ICM, Nijkeuter M, Righini M, Perrier A, Le Gal G, Huisman MV (2008) Simplification of the revised Geneva score for assessing clinical probability of pulmonary embolism. Arch Intern Med 168:2131-2136. https://doi.org/10.1001/archi nte.168.19.2131

37. Douma RA, Mos ICM, Erkens PMG, Nizet TAC, Durian MF, Hovens MM, van Houten AA, Hofstee HMA, Klok FA, ten Cate H, Ullmann EF, Büller HR, Kamphuisen PW, Huisman MV, Prometheus Study Group (2011) Performance of 4 clinical decision rules in the diagnostic management of acute pulmonary embolism: a prospective cohort study. Ann Intern Med 154:709-718. https://doi.org/10.7326/0003-4819-154-11-201106070-00002

38. Carrier M, Righini M, Djurabi RK, Huisman MV, Perrier A, Wells PS, Rodger M, Wuillemin WA, Le Gal G (2009) VIDAS D-dimer in combination with clinical pre-test probability to rule out pulmonary embolism. A systematic review of management outcome studies. Thromb Haemost 101:886-892

39. Wu H, Birmingham DJ, Rovin B, Hackshaw KV, Haddad N, Haden D, Yu C-Y, Hebert LA (2008) D-dimer level and the risk for thrombosis in systemic lupus erythematosus. CJASN 3:16281636. https://doi.org/10.2215/CJN.01480308

40. Lindner G, Funk G-C, Pfortmueller CA, Leichtle AB, Fiedler GM, Schwarz C, Exadaktylos AK, Puig S (2014) D-dimer to rule out pulmonary embolism in renal insufficiency. Am J Med 127:343-347. https://doi.org/10.1016/j.amjmed.2013.12.003

41. Sharp AL, Vinson DR, Alamshaw F, Handler J, Gould MK (2016) An age-adjusted D-dimer threshold for emergency department patients with suspected pulmonary embolus: accuracy and clinical implications. Ann Emerg Med 67:249-257. https://doi. org/10.1016/j.annemergmed.2015.07.026

42. Stein PD, Fowler SE, Goodman LR, Gottschalk A, Hales CA, Hull RD, Leeper KV, Popovich J, Quinn DA, Sos TA, Sostman HD, Tapson VF, Wakefield TW, Weg JG, Woodard PK, PIOPED II Investigators (2006) Multidetector computed tomography for acute pulmonary embolism. N Engl J Med 354:2317-2327. https ://doi.org/10.1056/NEJMoa052367

43. Moore AJE, Wachsmann J, Chamarthy MR, Panjikaran L, Tanabe Y, Rajiah P (2018) Imaging of acute pulmonary embolism: an update. Cardiovasc Diagn Ther 8:225-243. https://doi. org/10.21037/cdt.2017.12.01

44. Squizzato A, Donadini MP, Galli L, Dentali F, Aujesky D, Ageno W (2012) Prognostic clinical prediction rules to identify a lowrisk pulmonary embolism: a systematic review and meta-analysis. J Thromb Haemost 10:1276-1290. https://doi.org/10.111 1/j.1538-7836.2012.04739.x

45. Kohn CG, Mearns ES, Parker MW, Hernandez AV, Coleman CI (2015) Prognostic accuracy of clinical prediction rules for early post-pulmonary embolism all-cause mortality: a bivariate 
meta-analysis. Chest 147:1043-1062. https://doi.org/10.1378/ chest.14-1888

46. Jiménez D, Aujesky D, Moores L, Gómez V, Lobo JL, Uresandi F, Otero R, Monreal M, Muriel A, Yusen RD, RIETE Investigators (2010) Simplification of the pulmonary embolism severity index for prognostication in patients with acute symptomatic pulmonary embolism. Arch Intern Med 170:1383-1389. https ://doi.org/10.1001/archinternmed.2010.199

47. Elias A, Mallett S, Daoud-Elias M, Poggi J-N, Clarke M (2016) Prognostic models in acute pulmonary embolism: a systematic review and meta-analysis. BMJ Open 6:e010324. https://doi. org/10.1136/bmjopen-2015-010324

48. Becattini C, Agnelli G (2016) Risk stratification and management of acute pulmonary embolism. Hematol Am Soc Hematol Educ Program 2016:404-412. https://doi.org/10.1182/asheducati on-2016.1.404

49. Konstantinides SV, Meyer G, Becattini C, Bueno H, Geersing G-J, Harjola V-P, Huisman MV, Humbert M, Jennings CS, Jiménez D, Kucher N, Lang IM, Lankeit M, Lorusso R, Mazzolai L, Meneveau N, Ní Áinle F, Prandoni P, Pruszczyk P, Righini M, Torbicki A, Van Belle E, Zamorano JL, Galié N, Gibbs JSR, Aboyans V, Ageno W, Agewall S, Almeida AG, Andreotti F, Barbato E, Bauersachs J, Baumbach A, Beygui F, Carlsen J, De Carlo M, Delcroix M, Delgado V, Subias PE, Fitzsimons D, Gaine S, Goldhaber SZ, Gopalan D, Habib G, Halvorsen S, Jenkins D, Katus HA, Kjellström B, Lainscak M, Lancellotti P, Lee G, Le Gal G, Messas E, Morais J, Petersen SE, Petronio AS, Piepoli MF, Price S, Roffi M, Salvi A, Sanchez O, Shlyakhto E, Simpson IA, Stortecky S, Thielmann M, Noordegraaf AV, Becattini C, Bueno H, Geersing G-J, Harjola V-P, Huisman MV, Humbert M, Jennings CS, Jiménez D, Kucher N, Lang IM, Lankeit M, Lorusso R, Mazzolai L, Meneveau N, Ní Áinle F, Prandoni P, Pruszczyk P, Righini M, Torbicki A, VanBelle E, LuisZamorano J, Windecker S, Aboyans V, Baigent C, Collet J-P, Dean V, Delgado V, Fitzsimons D, Gale CP, Grobbee D, Halvorsen S, Hindricks G, Iung B, Jüni P, Katus HA, Landmesser U, Leclercq C, Lettino M, Lewis BS, Merkely B, Mueller C, Petersen SE, Sonia Petronio A, Richter DJ, Roffi M, Shlyakhto E, Simpson IA, Sousa-Uva M, Touyz RM, Hammoudi N, Hayrapetyan H, Mascherbauer J, Ibrahimov F, Polonetsky O, Lancellotti P, Tokmakova M, Skoric B, Michaloliakos I, Hutyra M, Mellemkjaer S, Mostafa M, Reinmets J, Jääskeläinen P, Angoulvant D, Bauersachs J, Giannakoulas G, Zima E, Vizza CD, Sugraliyev A, Bytyçi I, Maca A, Ereminiene E, Huijnen S, Xuereb R, Diaconu N, Bulatovic N, Asfalou I, Bosevski M, Halvorsen S, Sobkowicz B, Ferreira D, Petris AO, Moiseeva O, Zavatta M, Obradovic S, Šimkova I, Radsel P, Ibanez B, Wikström G, Aujesky D, Kaymaz C, Parkhomenko A, Pepke-Zaba J (2020) 2019 ESC Guidelines for the diagnosis and management of acute pulmonary embolism developed in collaboration with the European Respiratory Society (ERS)The Task Force for the diagnosis and management of acute pulmonary embolism of the European Society of Cardiology (ESC). Eur Heart J 41:543-603. https://doi.org/10.1093/ eurheartj/ehz405

50. Bova C, Sanchez O, Prandoni P, Lankeit M, Konstantinides S, Vanni S, Jiménez D (2014) Identification of intermediate-risk patients with acute symptomatic pulmonary embolism. Eur Respir J 44:694-703. https://doi.org/10.1183/09031936.00006 114

51. Fernández C, Bova C, Sanchez O, Prandoni P, Lankeit M, Konstantinides S, Vanni S, Fernández-Golfín C, Yusen RD, Jiménez D (2015) Validation of a model for identification of patients at intermediate to high risk for complications associated with acute symptomatic pulmonary embolism. Chest 148:211-218. https:// doi.org/10.1378/chest.14-2551
52. Hobohm L, Hellenkamp K, Hasenfuß G, Münzel T, Konstantinides S, Lankeit M (2016) Comparison of risk assessment strategies for not-high-risk pulmonary embolism. Eur Respir J 47:1170-1178. https://doi.org/10.1183/13993003.01605-2015

53. Jimenez D, Lobo JL, Fernandez-Golfin C, Portillo AK, Nieto R, Lankeit M, Konstantinides S, Prandoni P, Muriel A, Yusen RD (2016) Effectiveness of prognosticating pulmonary embolism using the ESC algorithm and the Bova score. Thromb Haemost 115:827-834. https://doi.org/10.1160/TH15-09-0761

54. Dellas C, Tschepe M, Seeber V, Zwiener I, Kuhnert K, Schäfer K, Hasenfuß G, Konstantinides S, Lankeit M (2014) A novel $\mathrm{H}-\mathrm{FABP}$ assay and a fast prognostic score for risk assessment of normotensive pulmonary embolism. Thromb Haemost 111:996-1003. https://doi.org/10.1160/TH13-08-0663

55. Lankeit M, Friesen D, Schäfer K, Hasenfuß G, Konstantinides S, Dellas C (2013) A simple score for rapid risk assessment of non-high-risk pulmonary embolism. Clin Res Cardiol 102:7380. https://doi.org/10.1007/s00392-012-0498-1

56. Kearon C, Akl EA, Comerota AJ, Prandoni P, Bounameaux H, Goldhaber SZ, Nelson ME, Wells PS, Gould MK, Dentali F, Crowther M, Kahn SR (2012) Antithrombotic therapy for VTE disease: antithrombotic therapy and prevention of thrombosis, 9th ed: American College of Chest Physicians Evidence-Based Clinical Practice Guidelines. Chest 141:e419S-e496S. https:// doi.org/10.1378/chest.11-2301

57. Mahar JH, Haddadin I, Sadana D, Gadre A, Evans N, Hornacek D, Mahlay NF, Gomes M, Joseph D, Serhal M, Tong MZ-Y, Bauer SR, Militello M, Silver B, Shishehbor M, Bartholomew JR, Heresi GA (2018) A pulmonary embolism response team (PERT) approach: initial experience from the Cleveland Clinic. J Thromb Thrombol 46:186-192. https://doi.org/10.1007/ s11239-018-1686-2

58. Serhal M, Haddadin IS, Heresi GA, Hornacek DA, Shishehbor MH, Bartholomew JR (2017) Pulmonary embolism response teams. J Thromb Thrombol 44:19-29. https://doi.org/10.1007/ s11239-017-1498-9

59. Chaudhury P, Gadre SK, Schneider E, Renapurkar RD, Gomes M, Haddadin I, Heresi GA, Tong MZ, Bartholomew JR (2019) Impact of multidisciplinary pulmonary embolism response team availability on management and outcomes. Am J Cardiol 124:1465-1469. https://doi.org/10.1016/j.amjcard.2019.07.043

60. Kuo WT (2012) Endovascular therapy for acute pulmonary embolism. J Vasc Interv Radiol 23:167-179. https://doi. org/10.1016/j.jvir.2011.10.012

61. Javed QA, Sista AK (2019) Endovascular therapy for acute severe pulmonary embolism. Int J Cardiovasc Imaging 35:1443-1452. https://doi.org/10.1007/s10554-019-01567-z

62. Piazza G, Hohlfelder B, Jaff MR, Ouriel K, Engelhardt TC, Sterling KM, Jones NJ, Gurley JC, Bhatheja R, Kennedy RJ, Goswami N, Natarajan K, Rundback J, Sadiq IR, Liu SK, Bhalla N, Raja ML, Weinstock BS, Cynamon J, Elmasri FF, Garcia MJ, Kumar M, Ayerdi J, Soukas P, Kuo W, Liu P-Y, Goldhaber SZ, SEATTLE II Investigators (2015) A prospective, single-arm, multicenter trial of ultrasound-facilitated, catheter-directed, low-dose fibrinolysis for acute massive and submassive pulmonary embolism: the SEATTLE II Study. JACC Cardiovasc Interv 8:1382-1392. https://doi. org/10.1016/j.jcin.2015.04.020

63. Kucher N, Boekstegers P, Müller OJ, Kupatt C, Beyer-Westendorf J, Heitzer T, Tebbe U, Horstkotte J, Müller R, Blessing E, Greif M, Lange P, Hoffmann R-T, Werth S, Barmeyer A, Härtel D, Grünwald H, Empen K, Baumgartner I (2014) Randomized, controlled trial of ultrasound-assisted catheter-directed thrombolysis for acute intermediate-risk pulmonary embolism. Circulation 129:479-486. https://doi.org/10.1161/CIRCULATIO NAHA.113.005544 
64. Skaf E, Beemath A, Siddiqui T, Janjua M, Patel NR, Stein PD (2007) Catheter-tip embolectomy in the management of acute massive pulmonary embolism. Am J Cardiol 99:415-420. https ://doi.org/10.1016/j.amjcard.2006.08.052

65. Kuo WT, Gould MK, Louie JD, Rosenberg JK, Sze DY, Hofmann LV (2009) Catheter-directed therapy for the treatment of massive pulmonary embolism: systematic review and meta-analysis of modern techniques. J Vasc Interv Radiol 20:1431-1440. https:// doi.org/10.1016/j.jvir.2009.08.002

66. Kuo WT, Banerjee A, Kim PS, DeMarco FJ, Levy JR, Facchini FR, Unver K, Bertini MJ, Sista AK, Hall MJ, Rosenberg JK, De Gregorio MA (2015) Pulmonary embolism response to fragmentation, embolectomy, and catheter thrombolysis (PERFECT): initial results from a prospective multicenter registry. Chest 148:667-673. https://doi.org/10.1378/chest.15-0119

67. Tapson VF, Sterling K, Jones N, Elder M, Tripathy U, Brower J, Maholic RL, Ross CB, Natarajan K, Fong P, Greenspon L, Tamaddon H, Piracha AR, Engelhardt T, Katopodis J, Marques V, Sharp ASP, Piazza G, Goldhaber SZ (2018) A randomized trial of the optimum duration of acoustic pulse thrombolysis procedure in acute intermediate-risk pulmonary embolism: The OPTALYSE PE Trial. JACC Cardiovasc Interv 11:1401-1410. https://doi.org/10.1016/j.jcin.2018.04.008

68. Remy-Jardin M, Pistolesi M, Goodman LR, Gefter WB, Gottschalk A, Mayo JR, Sostman HD (2007) Management of suspected acute pulmonary embolism in the era of CT angiography: a statement from the Fleischner Society. Radiology 245:315-329. https://doi.org/10.1148/radiol.2452070397

69. Winer-Muram HT, Rydberg J, Johnson MS, Tarver RD, Williams MD, Shah H, Namyslowski J, Conces D, Jennings SG, Ying J, Trerotola SO, Kopecky KK (2004) Suspected acute pulmonary embolism: evaluation with multi-detector row CT versus digital subtraction pulmonary arteriography. Radiology 233:806-815. https://doi.org/10.1148/radiol.2333031744

70. Ruzsics B, Lee H, Zwerner PL, Gebregziabher M, Costello P, Schoepf UJ (2008) Dual-energy CT of the heart for diagnosing coronary artery stenosis and myocardial ischemia-initial experience. Eur Radiol 18:2414-2424. https://doi.org/10.1007/s0033 0-008-1022-x

71. Kalisz K, Halliburton S, Abbara S, Leipsic JA, Albrecht MH, Schoepf UJ, Rajiah P (2017) Update on cardiovascular applications of multienergy CT. RadioGraphics 37:1955-1974. https:// doi.org/10.1148/rg.2017170100

72. Rajiah P, Tanabe Y, Partovi S, Moore A (2019) State of the art: utility of multi-energy CT in the evaluation of pulmonary vasculature. Int J Cardiovasc Imaging 35:1509-1524. https://doi. org/10.1007/s10554-019-01615-8

73. Otrakji A, Digumarthy SR, Lo Gullo R, Flores EJ, Shepard J-AO, Kalra MK (2016) Dual-energy CT: spectrum of thoracic abnormalities. Radiographics 36:38-52. https://doi.org/10.1148/ rg.2016150081

74. Kang M-J, Park CM, Lee C-H, Goo JM, Lee HJ (2010) Dualenergy CT: clinical applications in various pulmonary diseases. Radiographics 30:685-698. https://doi.org/10.1148/rg.30309 5101

75. Kim NH, Delcroix M, Jenkins DP, Channick R, Dartevelle P, Jansa P, Lang I, Madani MM, Ogino H, Pengo V, Mayer E (2013) Chronic thromboembolic pulmonary hypertension. J Am Coll Cardiol 62:D92-99. https://doi.org/10.1016/j.jacc.2013.10.024

76. Masy M, Giordano J, Petyt G, Hossein-Foucher C, Duhamel A, Kyheng M, De Groote P, Fertin M, Lamblin N, Bervar J-F, Remy J, Remy-Jardin M (2018) Dual-energy CT (DECT) lung perfusion in pulmonary hypertension: concordance rate with V/Q scintigraphy in diagnosing chronic thromboembolic pulmonary hypertension (CTEPH). Eur Radiol 28:5100-5110. https://doi. org/10.1007/s00330-018-5467-2
77. Godoy MCB, Heller SL, Naidich DP, Assadourian B, Leidecker C, Schmidt B, Vlahos I (2011) Dual-energy MDCT: comparison of pulmonary artery enhancement on dedicated CT pulmonary angiography, routine and low contrast volume studies. Eur J Radiol 79:e11-17. https://doi.org/10.1016/j.ejrad.2009.12.030

78. Jones SE, Wittram C (2005) The indeterminate CT pulmonary angiogram: imaging characteristics and patient clinical outcome. Radiology 237:329-337. https://doi.org/10.1148/radio 1.2371041520

79. Apfaltrer P, Bachmann V, Meyer M, Henzler T, Barraza JM, Gruettner J, Walter T, Schoepf UJ, Schoenberg SO, Fink C (2012) Prognostic value of perfusion defect volume at dual energy CTA in patients with pulmonary embolism: correlation with CTA obstruction scores, CT parameters of right ventricular dysfunction and adverse clinical outcome. Eur J Radiol 81:3592-3597. https://doi.org/10.1016/j.ejrad.2012.02.008

80. Delesalle M-A, Pontana F, Duhamel A, Faivre J-B, Flohr T, Tacelli N, Remy J, Remy-Jardin M (2013) Spectral optimization of chest CT angiography with reduced iodine load: experience in 80 patients evaluated with dual-source, dual-energy CT. Radiology 267:256-266. https://doi.org/10.1148/radio 1.12120195

81. Dong J, Wang X, Jiang X, Gao L, Li F, Qiu J, Xu Y, Wang H (2013) Low-contrast agent dose dual-energy CT monochromatic imaging in pulmonary angiography versus routine CT. J Comput Assist Tomogr 37:618-625. https://doi.org/10.1097/RCT.0b013 e31828f5020

82. Lu GM, Luo S, Meinel FG, McQuiston AD, Zhou CS, Kong X, Zhao YE, Zheng L, Schoepf UJ, Zhang LJ (2014) High-pitch computed tomography pulmonary angiography with iterative reconstruction at $80 \mathrm{kVp}$ and $20 \mathrm{~mL}$ contrast agent volume. Eur Radiol 24:3260-3268. https://doi.org/10.1007/s0033 0-014-3365-9

83. McLaughlin PD, Liang T, Homiedan M, Louis LJ, O'Connell TW, Krzymyk K, Nicolaou S, Mayo JR (2015) High pitch, low voltage dual source CT pulmonary angiography: assessment of image quality and diagnostic acceptability with hybrid iterative reconstruction. Emerg Radiol 22:117-123. https://doi. org/10.1007/s10140-014-1230-4

84. Albrecht MH, Bickford MW, Nance JW, Zhang L, De Cecco CN, Wichmann JL, Vogl TJ, Schoepf UJ (2016) State-of-the-art pulmonary CT angiography for acute pulmonary embolism. Am J Roentgenol 208:495-504. https://doi.org/10.2214/AJR.16.17202

85. O'Hora L, Foley SJ (2018) Iterative reconstruction and automatic tube voltage selection reduce clinical CT radiation doses and image noise. Radiography (Lond) 24:28-32. https://doi. org/10.1016/j.radi.2017.08.010

86. Sauter A, Koehler T, Brendel B, Aichele J, Neumann J, Noël P, Rummeny E, Muenzel D (2019) CT pulmonary angiography: dose reduction via a next generation iterative reconstruction algorithm. Acta Radiol 60:478-487. https://doi.org/10.1177/02841 85118784976

87. Becattini C, Agnelli G, Vedovati MC, Pruszczyk P, Casazza F, Grifoni S, Salvi A, Bianchi M, Douma R, Konstantinides S, Lankeit M, Duranti M (2011) Multidetector computed tomography for acute pulmonary embolism: diagnosis and risk stratification in a single test. Eur Heart J 32:1657-1663. https://doi. org/10.1093/eurheartj/ehr108

88. Ameli-Renani S, Rahman F, Nair A, Ramsay L, Bacon JL, Weller A, Sokhi HK, Devaraj A, Madden B, Vlahos I (2014) Dual-energy CT for imaging of pulmonary hypertension: challenges and opportunities. Radiographics 34:1769-1790. https:// doi.org/10.1148/rg.347130085

89. Renapurkar RD, Bolen MA, Shrikanthan S, Bullen J, Karim W, Primak A, Heresi GA (2018) Comparative assessment of qualitative and quantitative perfusion with dual-energy CT and planar 
and SPECT-CT V/Q scanning in patients with chronic thromboembolic pulmonary hypertension. Cardiovasc Diagn Ther 8:414-422. https://doi.org/10.21037/cdt.2018.05.07

90. Nakazawa T, Watanabe Y, Hori Y, Kiso K, Higashi M, Itoh T, Naito H (2011) Lung perfused blood volume images with dual-energy computed tomography for chronic thromboembolic pulmonary hypertension: correlation to scintigraphy with singlephoton emission computed tomography. J Comput Assist Tomogr 35:590-595. https://doi.org/10.1097/RCT.0b013e318224e227

91. Thieme SF, Ashoori N, Bamberg F, Sommer WH, Johnson TRC, Leuchte H, Becker A, Maxien D, Helck AD, Behr J, Reiser MF, Nikolaou K (2012) Severity assessment of pulmonary embolism using dual energy CT-correlation of a pulmonary perfusion defect score with clinical and morphological parameters of blood oxygenation and right ventricular failure. Eur Radiol 22:269278. https://doi.org/10.1007/s00330-011-2267-3

92. Rengier F, Melzig C, Derlin T, Marra AM, Vogel-Claussen J (2019) Advanced imaging in pulmonary hypertension: emerging techniques and applications. Int J Cardiovasc Imaging 35:14071420. https://doi.org/10.1007/s10554-018-1448-4

93. Renapurkar RD, Shrikanthan S, Heresi GA, Lau CT, Gopalan D (2017) Imaging in chronic thromboembolic pulmonary hypertension. J Thorac Imaging 32:71-88. https://doi.org/10.1097/ RTI.0000000000000256

94. Truong QA, Massaro JM, Rogers IS, Mahabadi AA, Kriegel MF, Fox CS, O'Donnell CJ, Hoffmann U (2012) Reference values for normal pulmonary artery dimensions by noncontrast cardiac computed tomography: the Framingham Heart Study. Circ Cardiovasc Imaging 5:147-154. https://doi.org/10.1161/CIRCI MAGING.111.968610

95. Alhamad EH, Al-Boukai AA, Al-Kassimi FA, Alfaleh HF, Alshamiri MQ, Alzeer AH, Al-Otair HA, Ibrahim GF, Shaik SA (2011) Prediction of pulmonary hypertension in patients with or without interstitial lung disease: reliability of CT findings. Radiology 260:875-883. https://doi.org/10.1148/radiol.11103 532

96. Ng CS, Wells AU, Padley SP (1999) A CT sign of chronic pulmonary arterial hypertension: the ratio of main pulmonary artery to aortic diameter. J Thorac Imaging 14:270-278. https://doi. org/10.1097/00005382-199910000-00007

97. Kang DK, Thilo C, Schoepf UJ, Barraza JM, Nance JW, Bastarrika G, Abro JA, Ravenel JG, Costello P, Goldhaber SZ (2011) CT Signs of right ventricular dysfunction: prognostic role in acute pulmonary embolism. JACC Cardiovasc Imaging 4:841849. https://doi.org/10.1016/j.jcmg.2011.04.013

98. Meinel FG, Nance JW, Schoepf UJ, Hoffmann VS, Thierfelder KM, Costello P, Goldhaber SZ, Bamberg F (2015) Predictive value of computed tomography in acute pulmonary embolism: systematic review and meta-analysis. Am J Med 128:747-759. e2. https://doi.org/10.1016/j.amjmed.2015.01.023

99. Becattini C, Agnelli G, Germini F, Vedovati MC (2014) Computed tomography to assess risk of death in acute pulmonary embolism: a meta-analysis. Eur Respir J 43:1678-1690. https:// doi.org/10.1183/09031936.00147813

100. Yeo JH, Zhou L, Lim R (2017) Indeterminate CT pulmonary angiogram: why and does it matter? J Med Imaging Radiat Oncol 61:18-23. https://doi.org/10.1111/1754-9485.12500

101. Chen Z, Deblois S, Toporowicz K, Boldeanu I, Francoeur M-O, Sadouni M, Lepanto L, Chartrand-Lefebvre C (2019) Yield of CT pulmonary angiography in the diagnosis of acute pulmonary embolism: short report. BMC Res Notes 12:41. https://doi. org/10.1186/s13104-019-4076-8

102. Bates DDB, Tkacz JN, LeBedis CA, Holalkere N (2016) Suboptimal CT pulmonary angiography in the emergency department: a retrospective analysis of outcomes in a large academic medical center. Emerg Radiol 23:603-607. https://doi.org/10.1007/s1014 $0-016-1425-y$

103. Ginsberg MS, King V, Panicek DM (2004) Comparison of interpretations of CT angiograms in the evaluation of suspected pulmonary embolism by on-call radiology fellows and subsequently by radiology faculty. AJR Am J Roentgenol 182:61-66. https:// doi.org/10.2214/ajr.182.1.1820061

104. Coche E, Verschuren F, Keyeux A, Goffette P, Goncette L, Hainaut P, Hammer F, Lavenne E, Zech F, Meert P, Reynaert MS (2003) Diagnosis of acute pulmonary embolism in outpatients: comparison of thin-collimation multi-detector row spiral CT and planar ventilation-perfusion scintigraphy. Radiology 229:757-765. https://doi.org/10.1148/radiol.2293020889

105. Ruiz Y, Caballero P, Caniego JL, Friera A, Olivera MJ, Tagarro D, Alvarez-Sala R (2003) Prospective comparison of helical CT with angiography in pulmonary embolism: global and selective vascular territory analysis. Interobserver agreement. Eur Radiol 13:823-829. https://doi.org/10.1007/s0033 0-002-1588-7

106. Remy-Jardin M, Remy J, Baghaie F, Fribourg M, Artaud D, Duhamel A (2000) Clinical value of thin collimation in the diagnostic workup of pulmonary embolism. AJR Am J Roentgenol 175:407-411. https://doi.org/10.2214/ajr.175.2.1750407

107. Ost D, Rozenshtein A, Saffran L, Snider A (2001) The negative predictive value of spiral computed tomography for the diagnosis of pulmonary embolism in patients with nondiagnostic ventilation-perfusion scans. Am J Med 110:16-21. https://doi. org/10.1016/s0002-9343(00)00641-0

108. Ghaye B, Szapiro D, Willems V, Dondelinger RF (2000) Combined CT venography of the lower limbs and spiral CT angiography of pulmonary arteries in acute pulmonary embolism: preliminary results of a prospective study. JBR-BTR 83:271-278

109. Crawford T, Yoon C, Wolfson K, Beller M, Emerick A, Goldin JG, Aberle DR (2001) The effect of imaging modality on patient management in the evaluation of pulmonary thromboembolism. J Thorac Imaging 16:163-169. https://doi.org/10.1097/00005 382-200107000-00004

110. Chartrand-Lefebvre C, Howarth N, Lucidarme O, Beigelman C, Cluzel P, Mourey-Gérosa I, Cadi M, Grenier P (1999) Contrastenhanced helical CT for pulmonary embolism detection: interand intraobserver agreement among radiologists with variable experience. AJR Am J Roentgenol 172:107-112. https://doi. org/10.2214/ajr.172.1.9888748

111. Mitjavila M, Balsa M, García-Cañamaque L, Gómez-Santos D, Penín FJ, Torres V, Gambí N, Pey C (2004) Helical CT and perfusion scintigraphy: diagnosis of pulmonary embolus in the clinical practice. Rev Esp Med Nucl 23:71-77. https://doi. org/10.1016/s0212-6982(04)72259-4

112. Doolittle DA, Froemming AT, Cox CW (2019) High-pitch versus standard mode CT pulmonary angiography: a comparison of indeterminate studies. Emerg Radiol 26:155-159. https://doi. org/10.1007/s10140-018-1656-1

113. Anderson DR, Barnes DC (2009) Computerized tomographic pulmonary angiography versus ventilation perfusion lung scanning for the diagnosis of pulmonary embolism. Curr Opin Pulm Med 15:425-429. https://doi.org/10.1097/MCP.0b013e3283 2d6b98

114. Sinzinger H, Rodrigues M, Kummer F (2013) Ventilation/perfusion lung scintigraphy. Multiple applications besides pulmonary embolism. Hell J Nucl Med 16:50-55. https://doi.org/10.1967/ s002449910072

115. Parker JA, Coleman RE, Grady E, Royal HD, Siegel BA, Stabin MG, Sostman HD, Hilson AJW (2012) SNM Practice guideline for lung scintigraphy 4.0. J Nucl Med Technol 40:57-65. https ://doi.org/10.2967/jnmt.111.101386 
116. Mattsson S, Johansson L, Leide Svegborn S, Liniecki J, Noßke D, Riklund KA, Stabin M, Taylor D, Bolch W, Carlsson S, Eckerman K, Giussani A, Söderberg L, Valind S, ICRP (2015) Radiation dose to patients from radiopharmaceuticals: a compendium of current information related to frequently used substances. Ann ICRP 44:7-321. https://doi.org/10.1177/0146645314558019

117. Einstein AJ, Henzlova MJ, Rajagopalan S (2007) Estimating risk of cancer associated with radiation exposure from 64-slice computed tomography coronary angiography. JAMA 298:317323. https://doi.org/10.1001/jama.298.3.317

118. Astani SA, Davis LC, Harkness BA, Supanich MP, Dalal I (2014) Detection of pulmonary embolism during pregnancy: comparing radiation doses of CTPA and pulmonary scintigraphy. Nucl Med Commun 35:704-711. https://doi.org/10.1097/ MNM.0000000000000114

119. Perisinakis K, Seimenis I, Tzedakis A, Damilakis J (2014) Perfusion scintigraphy versus 256-slice CT angiography in pregnant patients suspected of pulmonary embolism: comparison of radiation risks. J Nucl Med 55:1273-1280. https://doi. org/10.2967/jnumed.114.137968

120. Rafat Motavalli L, Hoseinian Azghadi E, Miri Hakimabad H, Akhlaghi P (2017) Pulmonary embolism in pregnant patients: assessing organ dose to pregnant phantom and its fetus during lung imaging. Med Phys 44:6038-6046. https://doi. org/10.1002/mp. 12558

121. Chan WS, Ray JG, Murray S, Coady GE, Coates G, Ginsberg JS (2002) Suspected pulmonary embolism in pregnancy: clinical presentation, results of lung scanning, and subsequent maternal and pediatric outcomes. Arch Intern Med 162:1170 1175. https://doi.org/10.1001/archinte.162.10.1170

122. Cahill AG, Stout MJ, Macones GA, Bhalla S (2009) Diagnosing pulmonary embolism in pregnancy using computed-tomographic angiography or ventilation-perfusion. Obstet Gynecol 114:124-129. https://doi.org/10.1097/AOG.0b013e3181a99de $\mathrm{f}$

123. Leung AN, Bull TM, Jaeschke R, Lockwood CJ, Boiselle PM, Hurwitz LM, James AH, McCullough LB, Menda Y, Paidas MJ, Royal HD, Tapson VF, Winer-Muram HT, Chervenak FA, Cody DD, McNitt-Gray MF, Stave CD, Tuttle BD, ATS/STR Committee on Pulmonary Embolism in Pregnancy (2011) An official American Thoracic Society/Society of thoracic radiology clinical practice guideline: evaluation of suspected pulmonary embolism in pregnancy. Am J Respir Crit Care Med 184:1200-1208. https ://doi.org/10.1164/rccm.201108-1575ST

124. Revel M-P, Cohen S, Sanchez O, Collignon M-A, Thiam R, Redheuil A, Meyer G, Frija G (2011) Pulmonary embolism during pregnancy: diagnosis with lung scintigraphy or CT angiography? Radiology 258:590-598. https://doi.org/10.1148/radio 1.10100986

125. Shahir K, Goodman LR, Tali A, Thorsen KM, Hellman RS (2010) Pulmonary embolism in pregnancy: CT pulmonary angiography versus perfusion scanning. AJR Am J Roentgenol 195:W214-220. https://doi.org/10.2214/AJR.09.3506

126. Balan KK, Critchley M, Vedavathy KK, Smith ML, Vinjamuri S (1997) The value of ventilation-perfusion imaging in pregnancy. Br J Radiol 70:338-340. https://doi.org/10.1259/ bjr.70.832.9166067

127. Scarsbrook AF, Bradley KM, Gleeson FV (2007) Perfusion scintigraphy: diagnostic utility in pregnant women with suspected pulmonary embolic disease. Eur Radiol 17:2554-2560. https:// doi.org/10.1007/s00330-007-0607-0

128. U-King-Ima JM, Freeman SJ, Boylan T, Cheow HK (2008) Quality of CT pulmonary angiography for suspected pulmonary embolus in pregnancy. Eur Radiol 18:2709-2715. https://doi. org/10.1007/s00330-008-1100-0

129. Zuckier LS, Moadel RM, Haramati LB, Freeman LM (2020) Diagnostic evaluation of pulmonary embolism during the COVID-19 pandemic. J Nucl Med 61:630-631. https://doi. org/10.2967/jnumed.120.245571

130. Sostman HD, Miniati M, Gottschalk A, Matta F, Stein PD, Pistolesi M (2008) Sensitivity and specificity of perfusion scintigraphy combined with chest radiography for acute pulmonary embolism in PIOPED II. J Nucl Med 49:1741-1748. https://doi. org/10.2967/jnumed.108.052217

131. Reinartz P, Wildberger JE, Schaefer W, Nowak B, Mahnken AH, Buell U (2004) Tomographic imaging in the diagnosis of pulmonary embolism: a comparison between V/Q lung scintigraphy in SPECT technique and multislice spiral CT. J Nucl Med 45:1501-1508

132. Benson DG, Schiebler ML, Repplinger MD, François CJ, Grist TM, Reeder SB, Nagle SK (2017) Contrast-enhanced pulmonary MRA for the primary diagnosis of pulmonary embolism: current state of the art and future directions. Br J Radiol. https://doi. org/10.1259/bjr.20160901

133. Benson DG, Schiebler ML, Nagle SK, François CJ (2017) Magnetic resonance imaging for the evaluation of pulmonary embolism. Top Magn Reson Imaging 26:145-151. https://doi. org/10.1097/RMR.0000000000000133

134. Aziz M, Krishnam M, Madhuranthakam AJ, Rajiah P (2019) Update on MR imaging of the pulmonary vasculature. Int J Cardiovasc Imaging 35:1483-1497. https://doi.org/10.1007/s1055 4-019-01603-y

135. Bitar R, Leung G, Perng R, Tadros S, Moody AR, Sarrazin J, McGregor C, Christakis M, Symons S, Nelson A, Roberts TP (2006) MR pulse sequences: what every radiologist wants to know but is afraid to ask. RadioGraphics 26:513-537. https:// doi.org/10.1148/rg.262055063

136. Groth M, Henes FO, Bannas P, Muellerleile K, Adam G, Regier M (2011) Intraindividual comparison of contrast-enhanced MRI and unenhanced SSFP sequences of stenotic and non-stenotic pulmonary artery diameters. Rofo 183:47-53. https://doi. org/10.1055/s-0029-1245568

137. Miyazaki M, Lee VS (2008) Nonenhanced MR angiography. Radiology 248:20-43. https://doi.org/10.1148/radiol.24810 71497

138. Wild JM, Marshall H, Bock M, Schad LR, Jakob PM, Puderbach M, Molinari F, Beek EJRV, Biederer J (2012) MRI of the lung (1/3): methods. Insights Imaging 3:345-353. https://doi. org/10.1007/s13244-012-0176-x

139. Nagle SK, Schiebler ML, Repplinger MD, François CJ, Vigen KK, Yarlagadda R, Grist TM, Reeder SB (2016) Contrast enhanced pulmonary magnetic resonance angiography for pulmonary embolism: Building a successful program. Eur J Radiol 85:553-563. https://doi.org/10.1016/j.ejrad.2015.12.018

140. Hadizadeh DR, Marx C, Gieseke J, Schild HH, Willinek WA (2014) High temporal and high spatial resolution MR angiography (4D-MRA). Fortschr Röntgenstr 186:847-859. https://doi. org/10.1055/s-0034-1366661

141. Korosec FR, Frayne R, Grist TM, Mistretta CA (1996) Timeresolved contrast-enhanced 3D MR angiography. Magn Reson Med 36:345-351. https://doi.org/10.1002/mrm.1910360304

142. Vigen KK, Peters DC, Grist TM, Block WF, Mistretta CA (2000) Undersampled projection-reconstruction imaging for time-resolved contrast-enhanced imaging. Magn Reson Med 43:170-176. https://doi.org/10.1002/(SICI) 1522-2594(20000 2)43:2<170:AID-MRM2>3.0.CO;2-P

143. Du YP, Parker DL, Davis WL, Cao G (1994) Reduction of partial-volume artifacts with zero-filled interpolation in 
three-dimensional MR angiography. J Magn Reson Imaging 4:733-741. https://doi.org/10.1002/jmri.1880040517

144. Du J, Bydder M (2007) High-resolution time-resolved contrastenhanced MR abdominal and pulmonary angiography using a spiral-TRICKS sequence. Magn Reson Med 58:631-635. https ://doi.org/10.1002/mrm.21298

145. Fink C, Ley S, Kroeker R, Requardt M, Kauczor H-U, Bock M (2005) Time-resolved contrast-enhanced three-dimensional magnetic resonance angiography of the chest: combination of parallel imaging with view sharing (TREAT). Invest Radiol 40:40-48

146. Steeden JA, Pandya B, Tann O, Muthurangu V (2015) Free breathing contrast-enhanced time-resolved magnetic resonance angiography in pediatric and adult congenital heart disease. J Cardiovasc Magn Reson 17:38. https://doi.org/10.1186/s1296 8-015-0138-9
147. Ingrisch M, Maxien D, Meinel FG, Reiser MF, Nikolaou K, Dietrich O (2016) Detection of pulmonary embolism with freebreathing dynamic contrast-enhanced MRI. J Magn Reson Imaging 43:887-893. https://doi.org/10.1002/jmri.25050

148. Budjan J, Attenberger UI, Schoenberg SO, Pietsch H, Jost G (2018) The impact of injector-based contrast agent administration in time-resolved MRA. Eur Radiol 28:2246-2253. https:// doi.org/10.1007/s00330-017-5178-0

Publisher's Note Springer Nature remains neutral with regard to jurisdictional claims in published maps and institutional affiliations. 